\title{
Intrastorm Variability of the Inland and Orographic Enhancement of a Sea-Effect Snowstorm in the Hokuriku Region of Japan
}

\author{
Peter G. Veals and W. James Steenburgh \\ Department of Atmospheric Sciences, University of Utah, Salt Lake City, Utah \\ SENTO NAKAI AND SATORU YAMAGUCHI \\ Snow and Ice Research Center, National Institute for Earth Science and Disaster Resilience, Nagaoka, Japan
}

(Manuscript received 27 November 2019, in final form 6 April 2020)

\begin{abstract}
A prolonged period of winter monsoonal flow brought heavy sea-effect snowfall to the Hokuriku region along the west coast of the Japanese island of Honshu from 2 to 7 February 2010. Snowfall in some locations exceeded $140 \mathrm{~cm}$, but the distribution within the event was highly variable. We examine the factors contributing to these variations using data from a Japan Meteorological Agency (JMA) C-band surveillance radar, JMA soundings, surface precipitation observations, and a Weather Research and Forecasting (WRF) Model simulation. There were three distinct periods during the event. Period 1 featured relatively weak flow with precipitation confined mainly to the coast and lowlands. Precipitation maxima were located where the flow ascended: 1) over terrain-blocked air, 2) at the foot of a high flow-normal barrier, or 3) relatively unimpeded over the lower mountain ranges. Flow strengthened during period 2, yielding stronger vertical velocities over the terrain with precipitation maxima shifting inland and to higher elevation. The flow strengthened further in period 3, with the precipitation maxima shifting higher in elevation and into the lee, with almost no precipitation falling in the lowlands. Thus, greater inland penetration and enhancement of precipitation occurred as the flow speed increased, but additional factors such as the subcloud sublimation of hydrometeors and the convective instability also contribute to differences between periods 2 and 3 . These results illustrate the importance of incident flow strength in modulating the distribution and enhancement of snowfall in global lake- and sea-effect regions.
\end{abstract}

\section{Introduction}

The precipitation distribution during lake- and seaeffect snowstorms is affected by a complex combination of air-sea interactions, coastal geometry, and, where elevated terrain is present, orographic processes. The Hokuriku region along the Sea of Japan (SOJ) coast of the Japanese island of Honshu (Fig. 1) presents an advantageous location to study such processes. The regional terrain includes a broad coastal plain, low hills, and mountain ranges of various shapes and sizes reaching as high as $3000 \mathrm{~m}$ above mean sea level (MSL). The Asian winter monsoon also brings prolific cool season sea-effect snowfall, with a broad spectrum of flows with varying kinematic and thermodynamic characteristics impinging upon this terrain. Interactions between these flows and the diverse terrain result in highly

Corresponding author: Peter G. Veals, peter.veals@utah.edu variable distributions of precipitation within and among storms. For example, events have produced as much as $1 \mathrm{~m}$ of snow in $24 \mathrm{~h}$ in coastal cities with little snow falling in the mountains, or $>2 \mathrm{~m}$ of snow in $96 \mathrm{~h}$ in the mountains with little snow falling in the coastal lowlands (Miyazawa 1968; Nakai et al. 2006).

Sea-effect periods typically feature moist convection within a convective boundary layer topped by a stable layer or inversion (e.g., Magono et al. 1966; Niziol et al. 1995; Nakai et al. 2005; Manabe 1957). This convection is often organized into one or more modes, which over the SOJ and Hokuriku region include: 1) longitudinal (L-mode) bands, 2) transverse (T-mode) bands, 3) vortices and polar lows spanning the mesoscale, 4) shoreline bands, 5) broad precipitation shields, and 6) precipitation confined to the mountain slopes (Nakai et al. 2005). L-mode bands are oriented quasi-parallel to the flow and occur during periods of weak directional shear within the PBL, whereas T-mode bands are oriented 

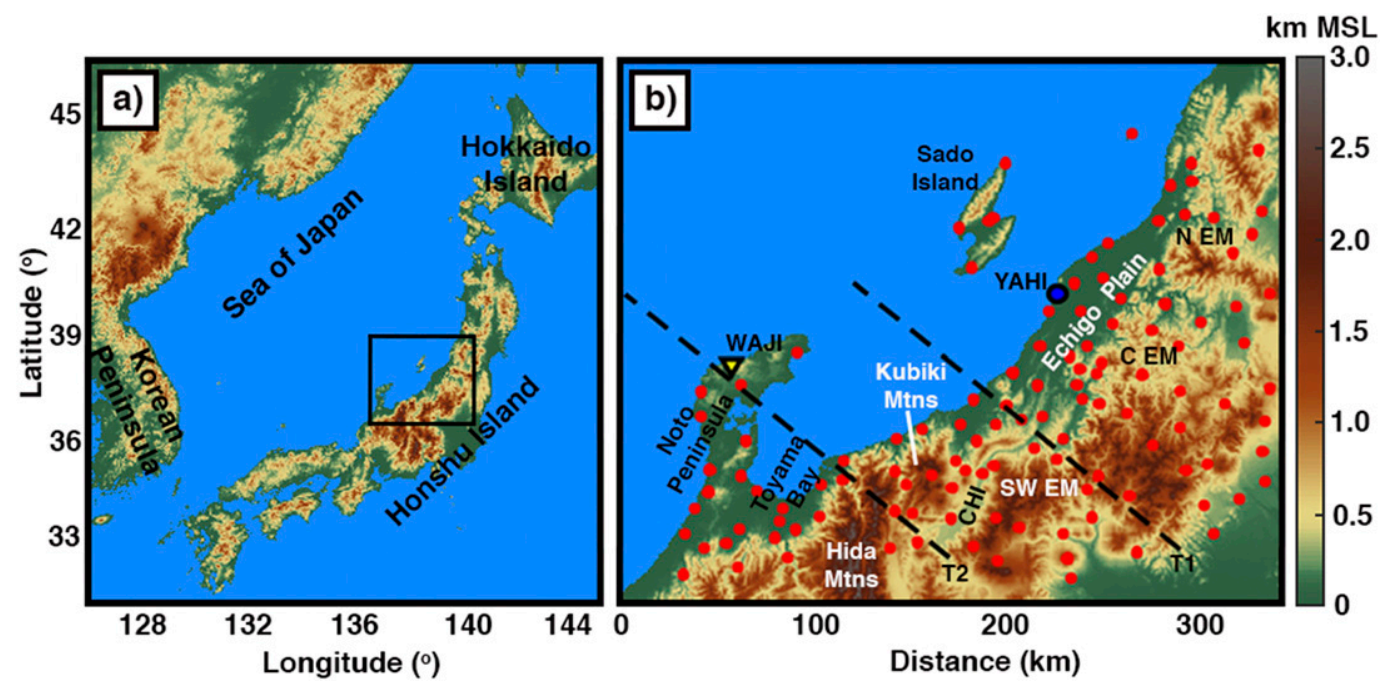

FIG. 1. Topography (km MSL following scale at right) of (a) the Japanese islands and surrounding region, with the location of the inset indicated by the black box. (b) The greater Hokuriku region, with major geographic features labeled. The locations of JMA and SIRC surface LPE observing sites are indicated by red dots, YAHI radar by the blue dot, and Wajima sounding site by the yellow triangle. Transects 1 and 2 are indicated by the dashed lines labeled T1 and T2, respectively. Abbreviated locations of interest include the Chikuma Valley (CHI), and the southwest (SW), central (C), and northern (N) Echigo Mountains (EM).

quasi normal to the flow and occur during periods of strong directional shear (e.g., Asai 1972; Miura 1986; Eito et al. 2010; Yamada et al. 2010). Broad, mesoscale snowbands can also be produced by the Japan Sea polar airmass convergence zone (JPCZ), which forms frequently over the western SOJ downstream of the base of the Korean Peninsula (e.g., Ohigashi and Tsuboki 2007; Eito et al. 2010; West et al. 2019). The JPCZ can produce intense precipitation where it intersects the coast of Honshu, most frequently between $\sim 133^{\circ}$ and $\sim 139^{\circ} \mathrm{E}$, including the Hokuriku region (Eito et al. 2010).

Sea-effect convection can be strongly forced by surface fluxes over the SOJ, with heat fluxes (latent plus sensible) as high as $600-900 \mathrm{~W} \mathrm{~m}^{-2}$ (e.g., Murakami et al. 1994; Dorman et al. 2004; Yoshizaki et al. 2004). These fluxes decrease abruptly upon landfall at the coast, frequently leading to convective-to-stratiform transition with inland extent (e.g., Kusunoki et al. 2004; Minder et al. 2015). Enhanced vertical motion and precipitation maxima can occur where land breezes oppose or converge with the large-scale flow, a process that can be reinforced by katabatic flow or blocking from the high coastal terrain in portions of the Hokuriku region (e.g., Ishihara et al. 1989; Eito et al. 2005). On the island of Hokkaido, Tachibana (1995) found this process to be most common during periods with cold temperatures and weak large-scale winds. The terrain of the Hokuriku region can also force strong convergence and ascent between the prevailing maritime flow and cold continental air, with one event having updrafts as deep as
$6.5 \mathrm{~km}$ with lightning and reflectivity $>45 \mathrm{dBZ}$ (Yoshihara et al. 2004).

The dynamical response of the large-scale flow to topography is crucial in determining the precipitation distribution in areas of complex terrain, and this response can be represented by the nondimensional mountain height

$$
\hat{H}=\frac{N_{d} h_{m}}{U},
$$

where $N_{d}$ is the dry Brunt-Väisälä frequency, $h_{m}$ is the height of the barrier, and $U$ is the component of the wind speed normal to the barrier. If the flow is saturated, stability can be represented by the moist Brunt-Väisälä frequency, $N_{m}$ (e.g., Fraser et al. 1973; Barcilon et al. 1979; Durran and Klemp 1982; Baines 1987; Jiang 2003). When $\hat{H}$ is low $(\hat{H} \ll 1)$, the flow will surmount the barrier and the maximum in vertical motion will be over the barrier. For periods where $\hat{H} \gg 1$, flow is blocked, resulting in a maximum in vertical motion that may be well upwind of the barrier or lateral to it as flow is forced around (e.g., Pierrhumbert and Wyman 1985; Smolarkiewicz and Rotunno 1989; Smith 1989; Galewsky 2008). During a sea-effect event in the Hokuriku region, Kusunoki et al. (2003) found that higher $\hat{H}$ periods tended to have shallow clouds confined to the windward slopes, with the precipitation deepening and moving over the barrier as $\hat{H}$ decreased. In another event, flow blocking maintained a persistent nearshore sea-effect band (Ohigashi et al. 2014). In addition to allowing flow to surmount a barrier, 
increasing wind speed can increase precipitation near and over a barrier by increasing the upslope moisture flux and the strength of the vertical motion (e.g., Neiman et al. 2002; Colle 2004; Yuter et al. 2011). Wind speed is also strongly correlated with the spillover of precipitation to the lee (e.g., Sinclair et al. 1997; Chater and Sturman 1998).

Another important factor in determining the distribution of precipitation is the time scale of the growth, transport, and fallout of hydrometeors. Smith and Barstad (2004) developed a relatively simple model that accounts for airflow dynamics, hydrometeor growth, advection, and evaporation and found it to perform well for nonconvective orographic precipitation. The reality can be more complicated, however, as nonlinear mountain-wave dynamics and the release of convective instability heavily influence the trajectory of hydrometeors (Geerts et al. 2015). Hydrometeor time scales are also important in lake-effect events, where a maximum in buoyancy occurs at landfall, often accompanied by a maximum in hydrometeor mixing ratio (Alcott and Steenburgh 2013; Campbell and Steenburgh 2017; Campbell et al. 2018). This effect is compounded by the tendency for fast-falling particles like graupel to occur more frequently and fall out closer to the shoreline than less-rimed particles (e.g., Harimaya and Sato 1992; Murakami et al. 1994; Harimaya and Kanemura 1995; Ohigashi and Tsuboki 2005). However, when terraininduced updrafts are sufficiently strong, high supercooled water concentrations and graupel can occur over inland areas (Kusunoki et al. 2005).

Sub-barrier-scale effects related to terrain shape and geometry can further affect the precipitation distribution. Watson and Lane $(2012,2014)$ showed that concavities within a barrier can provide additional enhancement beyond that of a straight barrier, with additional effects from the length and steepness of the barrier. Small ridges and corrugations within a mountain range can also provide strong local enhancement (e.g., Garvert et al. 2007; Minder et al. 2008; Campbell and Steenburgh 2014). In the Hokuriku region, Kusunoki et al. (2005) showed that supercooled water maxima were strongly tied to each sub peak in the terrain, with riming from these maxima contributing to orographic enhancement.

The motivation for this study comes from Veals et al. (2019, hereafter V19), who examined the factors affecting the inland and orographic enhancement of seaeffect periods during 9 cool seasons. They found that the strength and direction of the flow in the planetary boundary layer (hereafter PBL) had the greatest effect upon the distribution and intensity of precipitation, with the distribution relative to the barrier well depicted by
$\hat{H}$. The sea-induced CAPE (SiCAPE) also had an influence upon the precipitation distribution and intensity. The present study seeks to understand how these factors relate to the dynamic and thermodynamic processes that modulate snowfall in an individual storm. To accomplish this, we focus on a prolonged event from 2 to 7 February 2010, which brought nearly continuous sea-effect snowfall to the Hokuriku region. The distribution of snowfall varied widely within the event, with snowfall during the early portion of the event falling almost exclusively in the coastal lowlands, and during the later portion falling almost exclusively in the higher elevations. Therefore, using observational data and a numerical simulation, this study seeks to explore and elucidate the causes of this intrastorm variability in the distribution and enhancement of precipitation.

\section{Data and methods}

\section{a. Observational data}

We characterize the large-scale atmospheric environment during the event using the ERA5 reanalysis (C3S 2017), available at $0.25^{\circ}$ horizontal grid spacing and 1-h temporal resolution. Radar reflectivity data for the event were obtained from a Japan Meteorological Agency (JMA) C-band surveillance radar, YAHI, located at $645 \mathrm{~m}$ MSL on Mt. Yahiko (Fig. 1b; see V19 for a blockage map). YAHI has a minimum elevation angle of $-0.5^{\circ}$, additional scans up to a maximum elevation angle of $25^{\circ}$, and full volumes available at 10 -min intervals. We interpolated the volume scans to a Cartesian grid with $0.01^{\circ}$ horizontal and $0.25 \mathrm{~km}$ vertical resolution using the Radx $\mathrm{C}++$ software package, and produced radarestimated liquid precipitation equivalent (LPE) using the $Z-S$ relationship described by Vasiloff (2001) and Campbell et al. (2016) and given by

$$
Z=75 S^{2},
$$

where $Z$ is the radar reflectivity factor $\left(\mathrm{mm}^{6} \mathrm{~m}^{-3}\right)$ and $S$ is the LPE rate $\left(\mathrm{mm} \mathrm{h}^{-1}\right)$.

The YAHI-derived LPE estimates are supplemented with LPE observations from surface observing sites within the study region, which are maintained by either the JMA or the Japanese National Institute for Earth Science and Disaster Resilience (NIED) Snow and Ice Research Center (SIRC) and utilize heated tippingbucket gauges (see V19 for a detailed description). There were 4 JMA sites with missing or obviously spurious data during the study period, leaving 114 JMA and 7 SIRC sites in the final analysis. 


\section{b. Numerical simulation}

A numerical simulation was performed using version 3.9 of the Advanced Research version of the Weather Research and Forecasting (WRF) Model (Skamarock et al. 2008). We use three one-way nested domains with 60 vertical levels, a 5000-m deep Rayleigh damping layer at the upper boundary, and horizontal grid spacings of 12, 4, and $1.33 \mathrm{~km}$ (Fig. 2). Physics parameterizations were chosen based on configurations used successfully in previous lake- and sea-effect studies (e.g., Alcott and Steenburgh 2013; Reeves and Dawson 2013; Conrick et al. 2015; McMillen and Steenburgh 2015; Campbell et al. 2018) and fidelity relative to observed precipitation totals. These parameterizations include the RRTMG longwave radiation (Iacono et al. 2008), Dudhia shortwave radiation (Dudhia 1989), revised MM5 surface layer (Jimenez et al. 2012), Noah land surface model (Chen and Dudhia 2001), YSU PBL (Hong et al. 2006), and Thompson microphysics (Thompson et al. 2008). The Kain-Fritsch 2 cumulus parameterization (Kain 2004) was used only for the $12-\mathrm{km}$ domain. The simulation was initialized at 1200 UTC 1 February and run until 0000 UTC 7 February using the ERA5 reanalysis at $0.25^{\circ}$ horizontal grid spacing for initial and 3-hourly lateral boundary conditions, initial land surface conditions, and initial snow coverage. Daily sea surface temperatures were obtained from the Global High Resolution Sea Surface Temperature (GHRSST) analysis. Patches of sea ice were evident in visible satellite imagery in several small bays along the Russian coast, but their spatial coverage was minimal and thus no attempt was made to include them in the simulation.

\section{Event overview and model validation}

\section{a. Synoptic evolution}

From 2 to 7 February 2010 a prolonged episode of cold winter monsoon flow across the SOJ brought heavy snowfall to the Hokuriku region including LPE and snowfall totals exceeding $110 \mathrm{~mm}$ and $140 \mathrm{~cm}$, respectively. We focus on three periods with contrasting seaeffect modes and precipitation distributions and use the ERA5 to present a synoptic overview.

During period 1 (1500 UTC 2 February-1500 UTC 3 February 2010), west-northwest (WNW) 500-hPa flow prevailed across the region, with weak cyclonic curvature (Fig. 3a). The strongest $500 \mathrm{hPa}$ vertical velocity signatures were mainly couplets of ascent/descent over the major mountain ranges of the region, including the mountains of northern Honshu, though subsidence prevailed across most of Honshu and the Hokuriku region. At $850 \mathrm{hPa}$, the geopotential height gradient was relatively

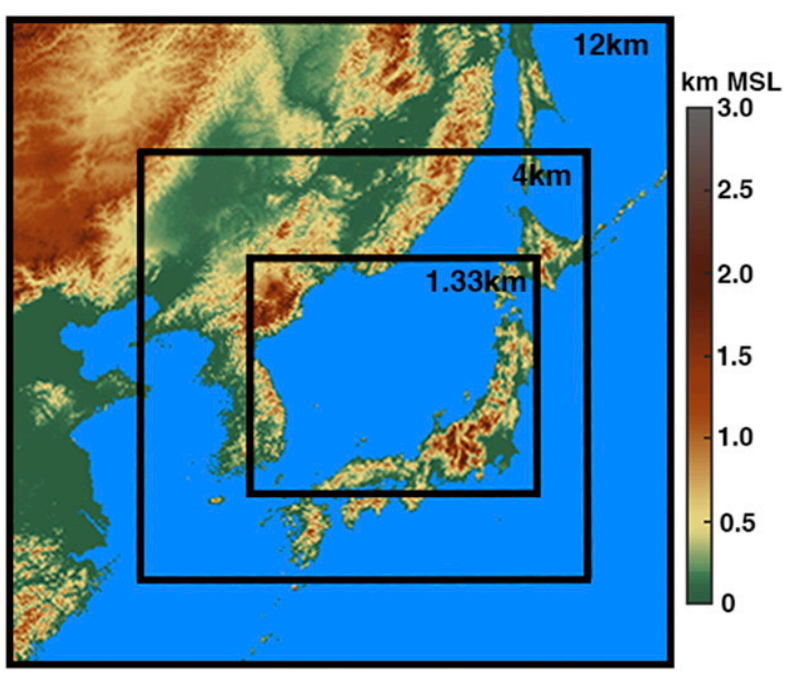

FIG. 2. WRF simulation domains, with topography (km MSL) following scale at right.

weak, with WNW winds of $7.5-15 \mathrm{~m} \mathrm{~s}^{-1}$ advecting cold Siberian air over the SOJ (Fig. 3b). With the cold air moving over the SOJ, moist convection initiated off the mainland Asia coast and extended downstream to Honshu and Hokkaido (Fig. 3c). The JPCZ was well defined over the southern portion of the sea, with a zone of T-mode convection extending to the north and making landfall in the Hokuriku region. The northern half of the SOJ, beginning near Sado Island, was covered mainly with L-mode convection.

During period 2 (0300 UTC 5 February-2200 UTC 5 February 2010), the $500 \mathrm{hPa}$ flow remained WNW over the SOJ, but strengthened as a shortwave trough moved into the region (Fig. 3d). As a result of the approaching trough, much more ascent was present in the vicinity of Honshu and over the Hokuriku region than in period 1, though the terrain-induced ascent/descent couplets remained somewhat intact. Cold air advection continued at $850 \mathrm{hPa}$, and a strengthening height gradient increased the WNW flow to $12.5-22.5 \mathrm{~m} \mathrm{~s}^{-1}$ over the central SOJ (Fig. 3e). Sea-effect convection continued, with the JPCZ still present and T-mode convection covering much of the SOJ, though some areas of L-mode convection remained (Fig. 3f). Although the JPCZ was well west of the Hokuriku region at the time presented, it did extend into the southwest portion at times early in period 2.

During period 3 (0000 UTC 6 February-2200 UTC 6 February 2010), the 500-hPa trough crossed over Honshu, with subsidence overspreading most of the region, except for a small region of ascent upstream of the high terrain of the Hokuriku region likely caused by flow moving over it (Fig. 3g). Further strengthening of the of 

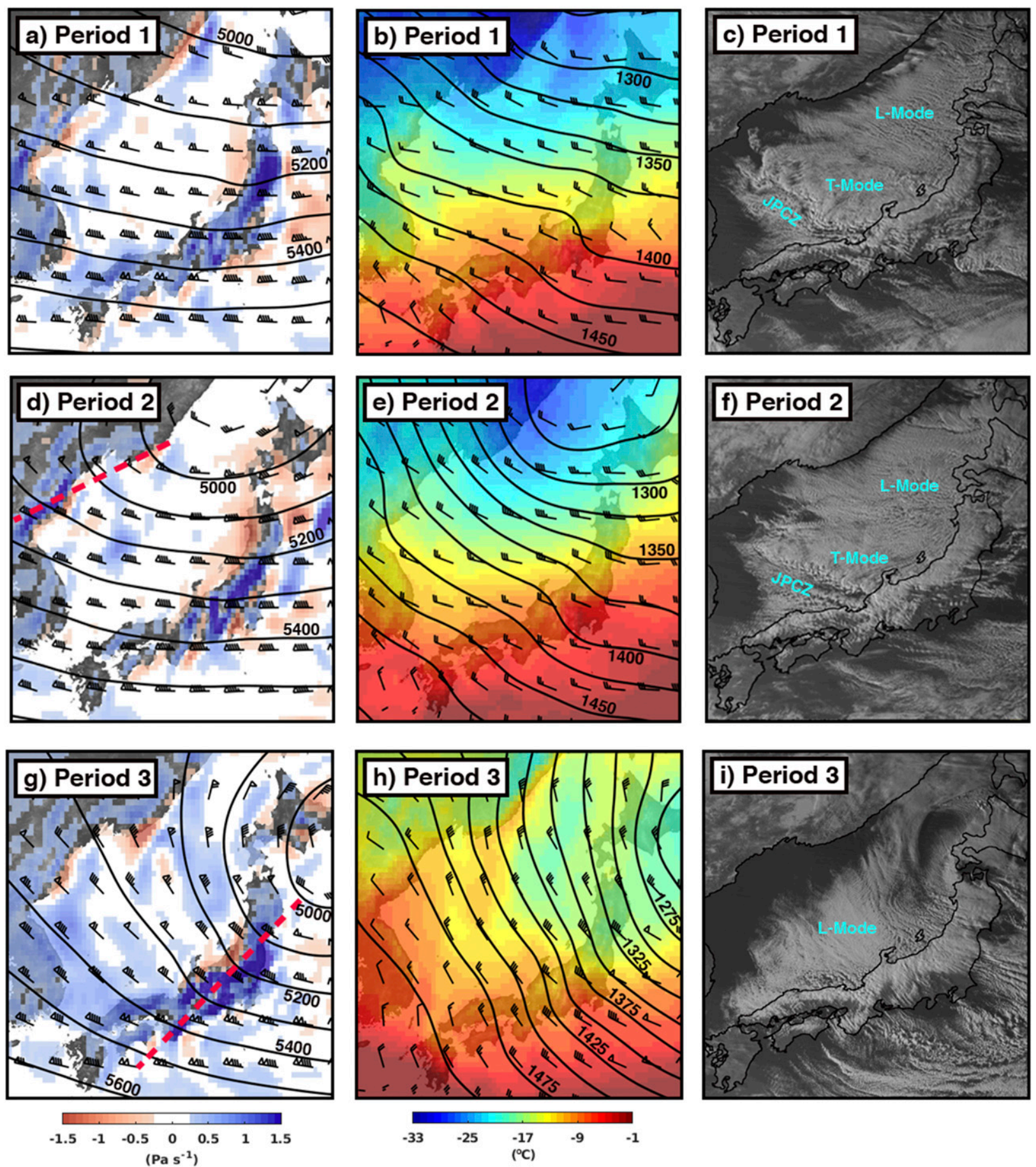

FIG. 3. The synoptic conditions during study period corresponding to (a)-(c) period 1 (0700 UTC 3 Feb), (d)-(f) period 2 (0700 UTC 5 Feb), and (g)-(i) period 3 (0700 UTC 6 Feb). Shown are (a),(d),(g) $500 \mathrm{hPa}$ geopotential height (m, contours), winds (full and half barbs denote 5 and $2.5 \mathrm{~m} \mathrm{~s}^{-1}$, respectively), and vertical velocity from the ERA5 reanalysis, (b),(e),(h) $850 \mathrm{hPa}$ geopotential height ( $\mathrm{m}$, contours), temperature, and winds from the ERA5 reanalysis, and (c),(f),(i) visible imagery from the MTSAT-1R geostationary satellite. Axes of upper-level troughs indicated by red dashed lines, with blue text indicating major features in the visible satellite imagery. 

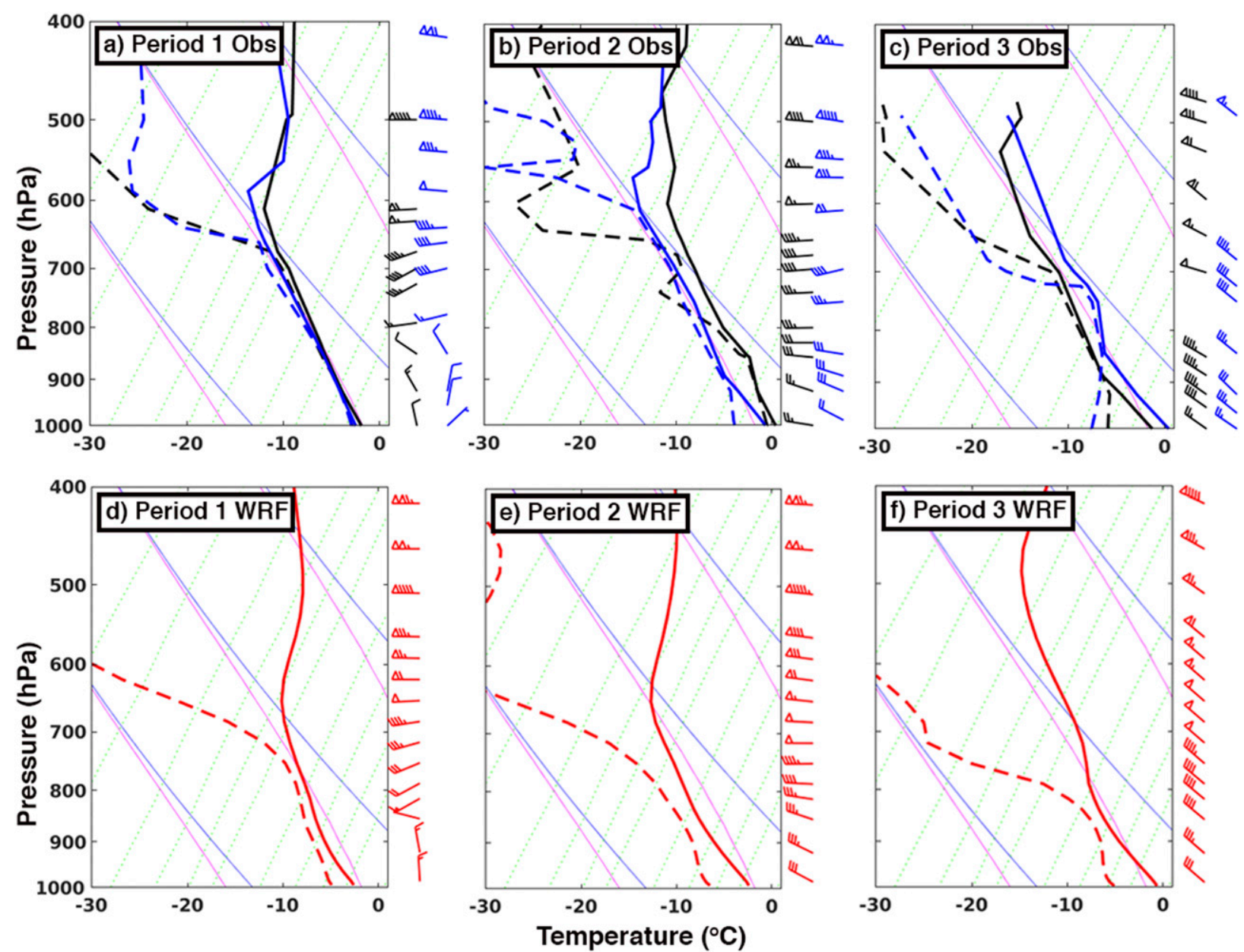

FIG. 4. Temperature and wind (full and half barbs denote 5 and $2.5 \mathrm{~m} \mathrm{~s}^{-1}$, respectively) data from the JMA sounding at Wajima at times corresponding to (a) period 1 (black indicates 0000 UTC 3 Feb sounding and blue indicates 1200 UTC 3 Feb sounding), (b) period 2 (black indicates 0000 UTC 5 Feb sounding and blue indicates 1200 UTC 5 Feb sounding), and (c) period 3 (black indicates 0000 UTC 6 Feb sounding and blue indicates 1200 UTC 6 Feb sounding). The mean WRF sounding for (d) period 1, (e) period 2, and (f) period 3 plotted in red. Temperature and dewpoint indicated by the solid and dashed lines, respectively.

the $850 \mathrm{hPa}$ height gradient yielded northwest winds of $17.5-22.5 \mathrm{~m} \mathrm{~s}^{-1}$ over the central SOJ, and although relatively cold air continued moving over the SOJ, cold air advection ceased (Fig. 3h). Sea-effect convection persisted, but initiated farther downstream of the mainland Asia coast (Fig. 3i). Convection over the SOJ was mainly L-mode and extended farther inland over Honshu, with sea-effect clouds extending uninterrupted across portions of Honshu and, in some cases redeveloping over the Pacific Ocean.

\section{b. Atmospheric profile}

The observed soundings at Wajima (WAJI in Fig. 1) corresponding to period 1, launched 0000 and 1200 UTC 3 February, indicate a deep saturated PBL with approximately moist-neutral stability up to $\sim 660 \mathrm{hPa}$ (Fig. 4a). This layer is strongly sheared, with light north-northwest flow near the surface backing to westerly at $800 \mathrm{hPa}$ and southwesterly at $700 \mathrm{hPa}$. The strong directional shear likely explains the prevalence of T-mode convection during this time. The corresponding WRF sounding is calculated by taking the spatial mean at the grid points within a $10 \mathrm{~km}$ radius of Wajima and averaging the 10-min output files over the duration of period 1 . Compared to the observed soundings, this WRF sounding agrees well with the temperature, moisture, and wind profiles from the surface to $700 \mathrm{hPa}$, but the atmosphere aloft is drier and the stable layer at the top of the PBL is lower and too smooth (it is still nearly as smooth at individual grid points before averaging). Within the PBL, WRF lapse rates are also greater near the surface and lesser aloft.

The Wajima soundings corresponding to period 2 (0000 and 1200 UTC 5 February) are warmer at the 
surface than those for period 1 (Fig. 4b). However, if the layer below $900 \mathrm{hPa}$ in the 1200 UTC 5 February sounding were moistened to saturation via evaporation and sublimation (as might be expected in precipitation cores), the temperature through much of the column would be roughly equal to that in period 1 (cf. Figs. $4 a, b)$. The winds in the lower half of the PBL are also much stronger than period 1 , with speeds below $800 \mathrm{hPa}$ two or three times greater in period 2. The wind profile in the WRF sounding generally agrees with the Wajima soundings, with winds in the layer below $800 \mathrm{hPa}$ in the $12.5-17.5 \mathrm{~m} \mathrm{~s}^{-1}$ range from the northwest, becoming westerly above that in the $17.5-25 \mathrm{~m} \mathrm{~s}^{-1}$ range (Figs. 4b,e). The WRF sounding again appears to produce a PBL that is both drier and shallower than the observed soundings, extending to $\sim 650 \mathrm{hPa}$, compared with $\sim 600 \mathrm{hPa}$ in the observed soundings. WRF temperatures are also slightly colder than observed throughout much of the column.

For period 3, the Wajima soundings show a deeper, drier subcloud layer than either of the previous periods, extending to $850-900 \mathrm{hPa}$ (Fig. 4c). Drying is also evident above $700 \mathrm{hPa}$, descending with time, likely a result of the synoptic-scale subsidence evident in Fig. $3 \mathrm{~g}$ as the upper-level trough exits the region. Temperatures are similar to period 2 , and warm with time, with a surface temperature near $0^{\circ} \mathrm{C}$ in the 1200 UTC 6 February sounding. Wind speeds in the 0000 UTC 6 February sounding are the strongest of the study period, with values at most levels $2.5-5 \mathrm{~m} \mathrm{~s}^{-1}$ greater than the corresponding values in period 2 . In the 1200 UTC 6 February sounding, speeds decrease to values similar to those observed in period 2. Contrary to the two previous periods, the winds do not back with height in period 3, with their unidirectional profile likely corresponding to the cessation of synoptic-scale cold air advection. This unidirectional profile also likely explains the change to L-mode convection for period 3. The WRF wind profile represents well the mean profile of the period, with values between those of the two observed soundings (cf. Figs. 4c,f). The temperature profile also agrees well, but the model does not do as well with the moisture profile. PBL top in the Wajima soundings is $\sim 730-700 \mathrm{hPa}$, compared to $\sim 800 \mathrm{hPa}$ in $\mathrm{WRF}$, and the subcloud layer in the observed sounding is drier.

Overall, the WRF mean soundings generally depict a similar evolution to that in the observed soundings. Period 1 features a deep and very moist sea-effect PBL, with relatively low wind speeds, especially in a layer of light northerly flow near the surface, with an abrupt transition to westerly flow above $850 \mathrm{hPa}$. Period 2 also features a deep and moist sea-effect PBL, though not quite as moist as period 1 , and with much stronger wind speeds throughout the column and a direction gradually backing with height. Period 3 features generally unidirectional winds with mean speeds similar or slightly stronger than period 2 throughout the column, with the shallowest and driest sea-effect PBL of the study period.

\section{c. Mesoscale structures and precipitation distribution}

To describe the mesoscale structure of the event, we first focus on radar and model-simulated reflectivity at a selected time during each period to show the characteristics of the precipitation structures. We then examine accumulated precipitation to understand the time-integrated behavior of these structures throughout each period.

Reflectivity from the YAHI radar at $1 \mathrm{~km}$ MSL during period 1 (0800 UTC 3 February) shows echoes with a roughly T-mode structure over the SOJ, with unorganized echoes elsewhere (Fig. 5a). Within the view of the radar, echoes are mainly over the lowlands and water with very few echoes apparent over the higher elevations of the Hida, Kubiki, or SW Echigo mountains. Over the N Echigo mountains, however, echoes are present farther into the higher elevations. The simulated reflectivity from WRF generally agrees with these characteristics (Fig. 5b). There are some T-mode bands over the SOJ, stronger echoes confined mainly to the lowlands, and few echoes over the Hida, Kubiki, or SW Echigo mountains. Some echoes penetrate into the N Echigo Mountains.

During period 2 (0800 UTC 5 February), YAHI shows T-mode convection continuing over the SOJ, but echoes have become numerous and strong over the foothills and windward terrain of the Hida, Kubiki, and SW Echigo Mountain (Fig. 5c). In the areas sampled by the YAHI beam, the corresponding WRF reflectivity has similar structures, with T-mode convection over the water and strong echoes over the foothills and windward terrain of the Hida, Kubiki, and SW Echigo Mountains (Fig. 5d). The wavelength of the T-mode rolls is larger in WRF than observed, perhaps reflecting a limitation of the model resolution in capturing finescale convective structures (Ching et al. 2014).

Period 3 is dominated by L-mode or open-cell convection over the SOJ, with the YAHI scan showing cells becoming broader, stronger, and more numerous over the terrain (Fig. 5e). WRF simulated reflectivity exhibits strong similarity, also producing open-cell and L-mode convective structures of comparable size, with cells broadening and intensifying as they approach the terrain (Fig. 5f). The coverage of cells over the northern Echigo Plain and mountains, however, is much sparser than that observed by YAHI. 

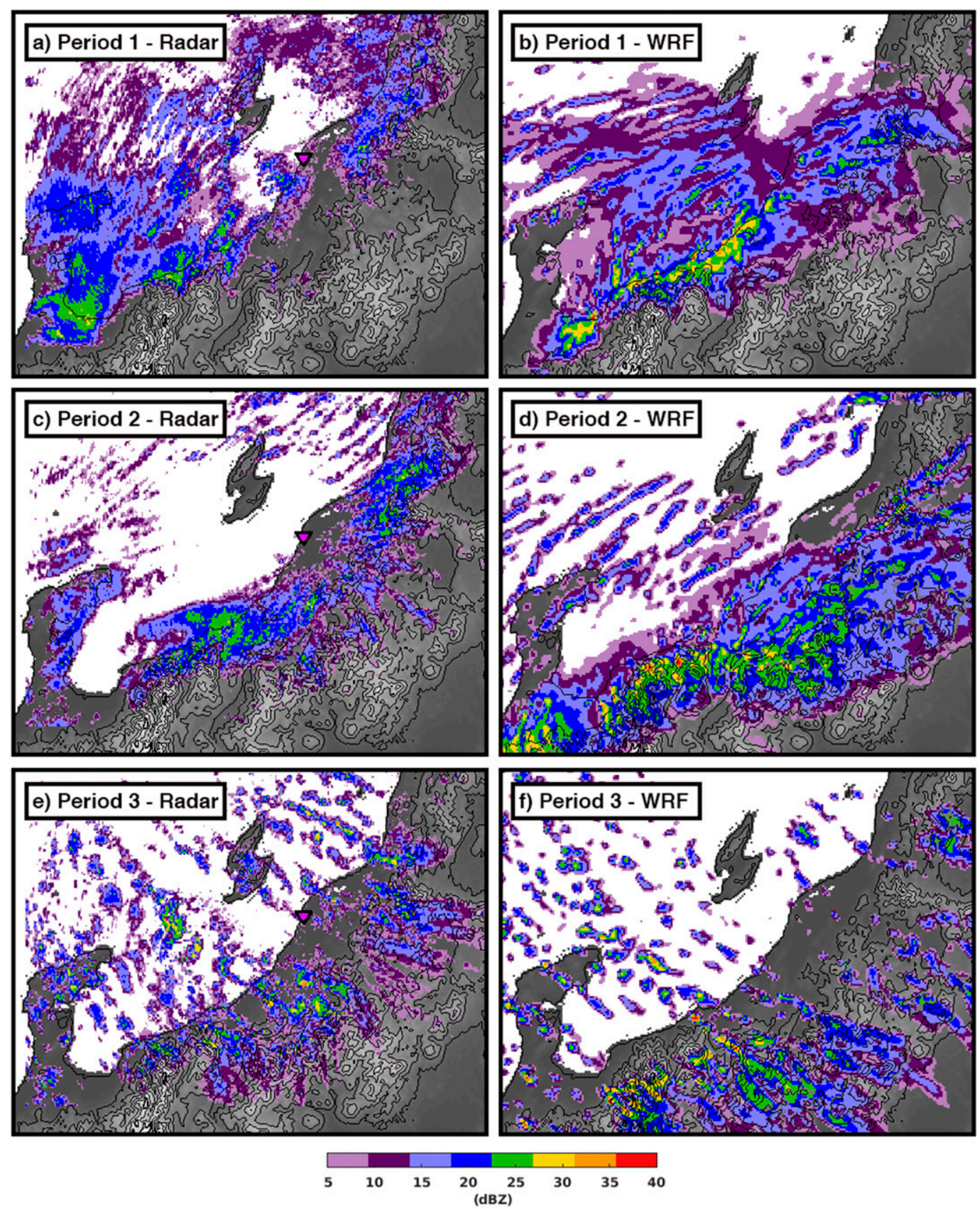

FIG. 5. (a),(c),(e) Observed $1 \mathrm{~km}$ MSL reflectivity from the YAHI radar and (b),(d),(f) WRF simulated reflectivity at times corresponding to (a),(b) period 1 (0800 UTC 3 Feb), (c),(d) period 2 (0800 UTC 5 Feb), and (e),(f) period 3 (0800 UTC $6 \mathrm{Feb}$ ). At points where elevation is $<1000 \mathrm{~m}$ MSL, WRF simulated reflectivity is interpolated to $1 \mathrm{~km} \mathrm{MSL}$, and near-surface reflectivity is used at points above that level. Terrain elevation contours every $400 \mathrm{~m}$ MSL. The magenta triangle indicates the location of YAHI.

Radar-derived LPE accumulations and totals from JMA and SIRC gauges during period 1 show the greatest values along the coast upwind of the Hida and Kubiki Mountains and over the lowlands of the southern and central Echigo Plain. Mean LPE rates exceed $2 \mathrm{~mm} \mathrm{~h}^{-1}$ at two sites, and little or no precipitation falls in the mountains (Fig. 6a). Farther north over the N Echigo mountains, however, the maximum shifts instead to higher elevations, where significant LPE accumulations occur. The LPE output from WRF generally agrees well with the observed patterns and magnitudes, with highest rates in both the observations and WRF extending along 

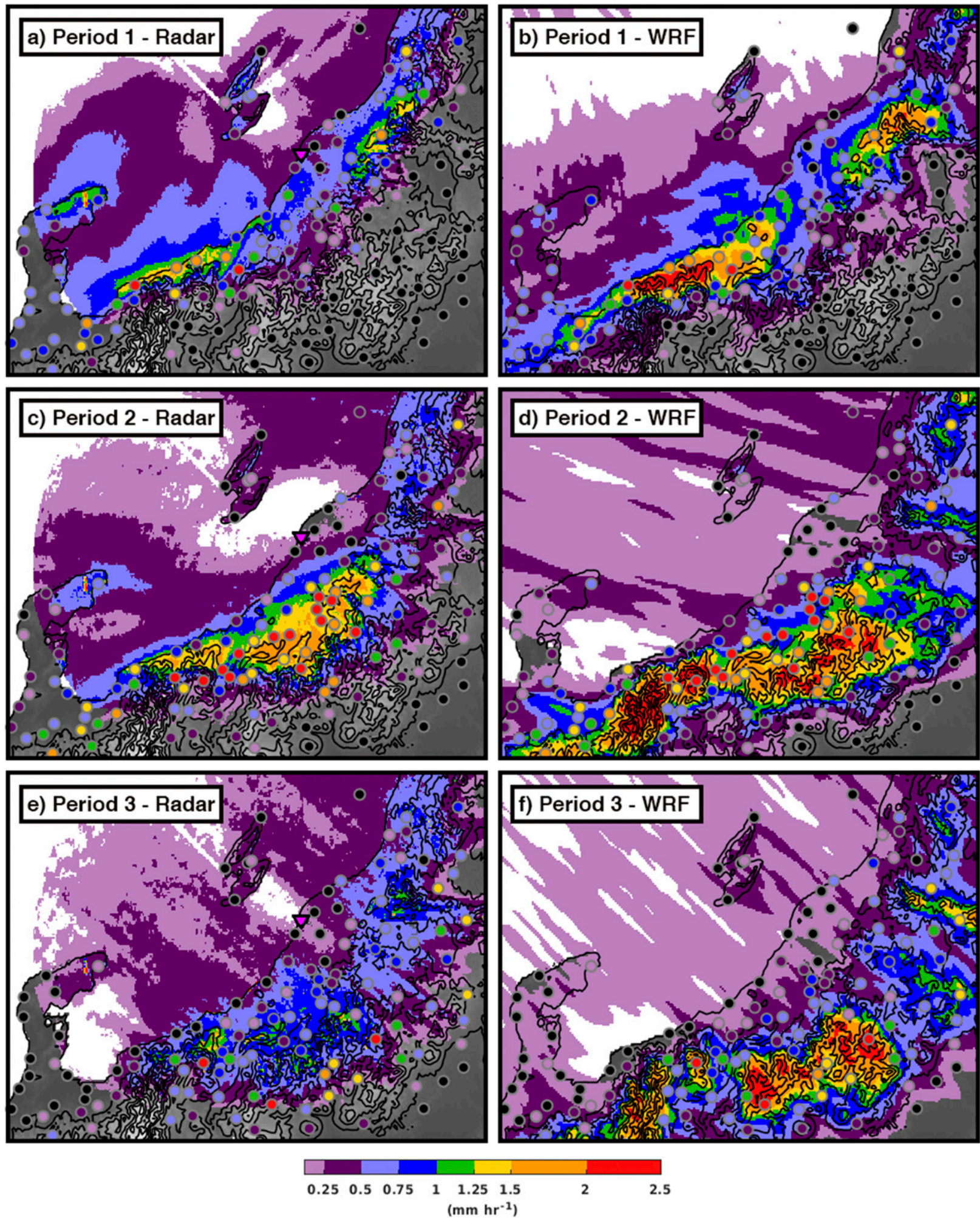

FIG. 6. LPE rate in color fill (a),(c),(e) estimated from YAHI and (b),(d),(f) produced by WRF for the duration of (a),(b) period 1, (c),(d) period 2, and (e),(f) period 3. LPE from YAHI is calculated up to points where the centroid of the lowest unblocked beam reaches $1 \mathrm{~km}$ above ground or the range ring corresponding to that height over the SOJ, whichever occurs first in the radial direction. Dots are overlaid at each JMA or SIRC observing site and colored according to the LPE total at the site. Black dots indicate values below the bottom end of the color scale $\left(<0.125 \mathrm{~mm} \mathrm{~h}^{-1}\right)$. Terrain elevation contours every $400 \mathrm{~m} \mathrm{MSL}$. The magenta triangle indicates the location of YAHI. 
the foot of the Hida and Kubiki mountains, and there is remarkable agreement in a localized maximum just south of Toyama bay (Figs. 6a,b). There is also good agreement in the moderate rates $\left(0.75-1.5 \mathrm{~mm} \mathrm{~h}^{-1}\right)$ in much of the Echigo Plain, a secondary maximum over the N Echigo Mountains, and a local decrease in the lee of Sado Island. One potential deficiency in WRF, however, is the underproduction of precipitation over the SOJ and near the tip of the Noto Peninsula as compared to the observations, although some island gauges agree better with WRF.

Period 2 sees an inland shift of the highest LPE values in both observations and WRF toward the higher elevations with lesser amounts in the lowlands (Figs. 6c,d). Much of the LPE maximum is now outside the limit of reliable sampling by the YAHI beam, but gauges and WRF suggest the highest values over the windward slopes of the Hida, Kubiki, and SW Echigo Mountains, with rates exceeding $2 \mathrm{~mm} \mathrm{~h}^{-1}$. However, WRF underproduces in some areas in the southern Echigo Plain, at the foot of the northern Hida and Kibuki Mountains, and again near the tip of the Noto Peninsula.

For period 3, the LPE distribution shifts even farther inland and higher in elevation. The highest elevations and leeside areas of the SW Echigo and Kubiki Mountains are again beyond coverage of the YAHI beam, but the gauge network in these areas indicates maxima over the highest peaks or even into the lee of these peaks, with rates $>2 \mathrm{~mm} \mathrm{~h}^{-1}$ (Fig. 6e). WRF also suggests such a distribution, with the highest amounts over or into the lee of most of the $>2000 \mathrm{~m}$ peaks in the region (Fig. 6f). On the other hand, lowland sites see almost no precipitation during period 3 , and WRF also depicts this quite well. In fact the LPE distribution, as compared to the gauges in areas of radar coverage, is arguably better depicted by WRF than the YAHIderived amounts. The high bias of the YAHI LPE relative to gauges could be due to 1) sublimation of hydrometeors below cloud base (and the radar beam) in the relatively dry PBL present during period 3 and/or 2) undercatch of hydrometeors by the gauges in the strong winds present during period 3 .

\section{d. Summary}

The WRF run captures the characteristics and evolution of the precipitation structures in the Hokuriku region well among the three periods, properly depicting the mode and location of convection over the SOJ for each period. It also produces LPE rates that agree well in both magnitude and distribution with observed values, with period 1 featuring heavy accumulations in the lowlands and almost no LPE at high elevations, period 2 featuring heavy accumulations at high elevations and lesser amounts in the lowlands, and period 3 featuring heavy accumulations at high elevations and into the lee with almost no LPE in the lowlands. The evolution of the flow in the study period is also well depicted by WRF, with speed, direction, and shear all in reasonably good agreement with the observed soundings. The evolution of the thermodynamic profile in WRF is similar to observed, though the sea-effect PBL is generally a bit shallower and drier than observed. With this relatively high fidelity of the WRF fields compared to observations, we deem the model performance sufficient for the purposes of this study, which is to determine the mechanisms driving the variability in the distribution and enhancement of precipitation during the study period.

\section{Sea-effect convection}

To understand the underlying causes of the precipitation distribution during the study period, we first examine the characteristics of, and forcing for, sea-effect convection. During period 1, the sum of the mean surface latent and sensible heat fluxes from WRF (hereafter simply heat flux) varies from around $400 \mathrm{~W} \mathrm{~m}^{-2}$ over the SOJ in the southern portion of the study region to around $650 \mathrm{~W} \mathrm{~m}^{-2}$ across the northern portion (Fig. 7a). The maximum most-unstable CAPE at each WRF grid point (MUCAPE) is relatively modest, with values of $100-200 \mathrm{~J} \mathrm{~kg}^{-1}$ throughout most of the SOJ (Fig. 7b). Examining a vertical cross section along transect $\mathrm{T} 1$, the equivalent potential temperature $\left(\theta_{e}\right)$ decreases with height to $\sim 1 \mathrm{~km}$ MSL over the SOJ, indicating a profile that is unstable for saturated parcels as it is warmed and moistened from the sea surface (Fig. 7c). Almost immediately upon landfall, this vertical $\theta_{e}$ gradient reverses, indicating an airmass stable for dry and moist adiabatic ascent.

During period 2, the heat flux increases dramatically, with values as high as $850 \mathrm{~W} \mathrm{~m}^{-2}$ across the north decreasing to $\sim 600 \mathrm{~W} \mathrm{~m}^{-2}$ in the south in open-water areas, with lower values in Toyama Bay (Fig. 7d). The WRF temperature profile in period 2 is only slightly cooler than in period 1 , thus the stronger winds in period 2 likely explain most of the increase in surface heat flux. MUCAPE correspondingly increases from period 1 to 2 , with widespread maxima above $300 \mathrm{~J} \mathrm{~kg}^{-1}$ across much of the SOJ (Fig. 7e). Upon landfall, MUCAPE decreases abruptly with inland extent. Along T1, $\theta_{e}$ decreases with height to $\sim 1.5 \mathrm{~km}$ MSL over the SOJ, again indicating a profile that is unstable for saturated parcels (Fig. 7f). In contrast to period 1, this moist-unstable 

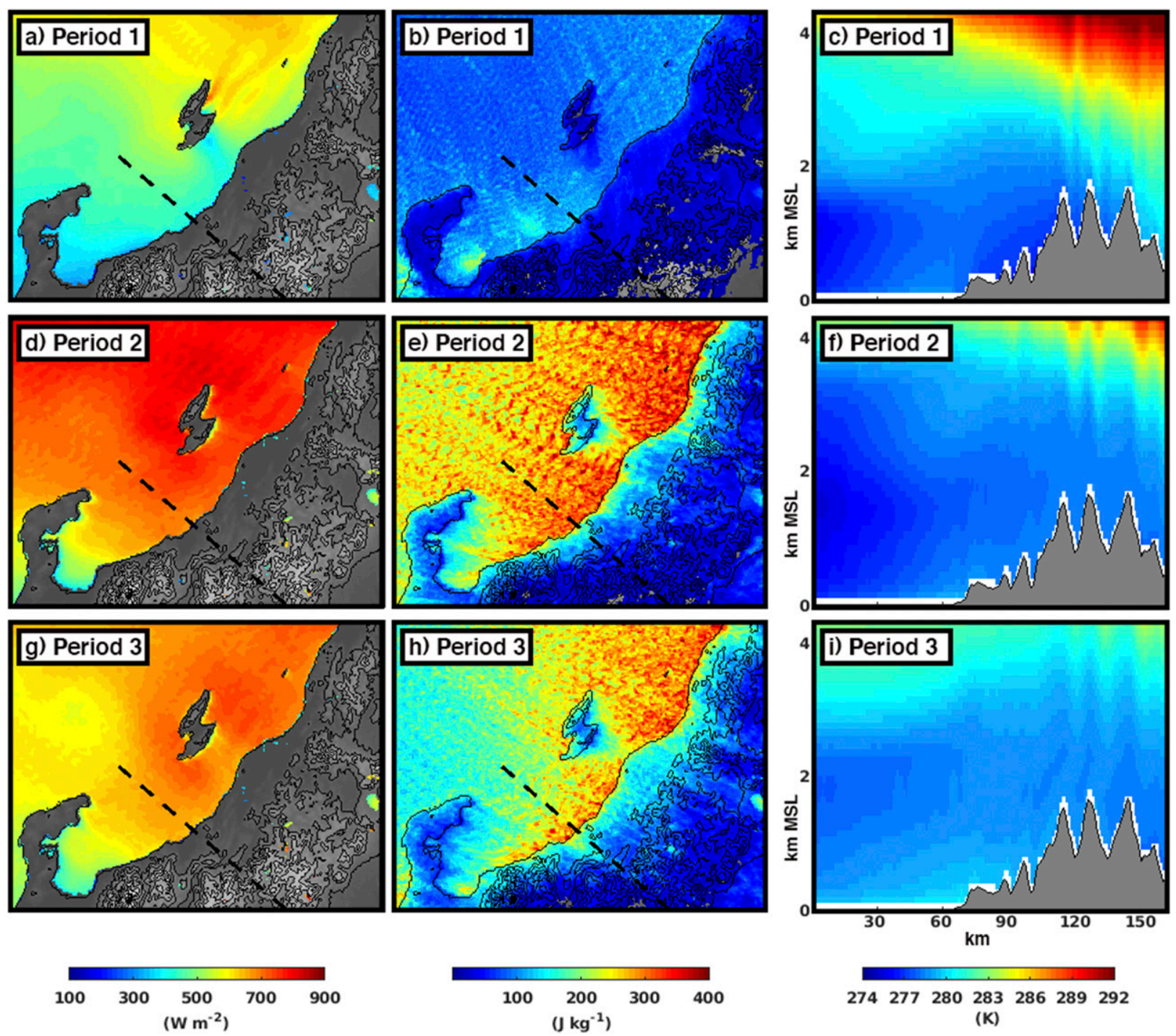

FIG. 7. (a),(d),(g) Mean latent + sensible surface heat flux, (b),(e),(h) most-unstable CAPE for parcels originating 0-2 km above ground at each point, and (c),(f),(i) mean $\theta_{e}$ along transect T1 for the duration of (a)-(c) period 1, (d)-(f) period 2, and (g)-(i) period 3. The dashed line indicates the location of $\mathrm{T} 1$.

profile extends farther inland before stabilizing over the high terrain.

Heat fluxes over the SOJ during period 3 are slightly lower than during period 2 , with values of $550-800 \mathrm{~W} \mathrm{~m}^{-2}$ over open water and lesser values again over Toyama Bay (Fig. $7 \mathrm{~g}$ ). This change reflects the effect of two competing factors, the slight increase in air temperature and slight increase in wind speed. The MUCAPE is correspondingly lower, with a much smaller area of the SOJ seeing values $>300 \mathrm{~J} \mathrm{~kg}^{-1}$ (Fig. 7h). This lesser convective instability relative to period 2 may contribute to the lesser LPE rates over the SOJ during period 3. MUCAPE in period 3 decreases with inland extent, but persists farther inland than in period 2 , likely owing to more rapid inland advection of the PBL by the slightly stronger flow. This assessment is supported by the $\theta_{e}$ profile along $\mathrm{T} 1$, which now features $\partial \theta_{e} / \partial Z<0$ extending from the overwater areas inland through the Echigo Plain, and to the first high peaks (Fig. 7i).

The stabilization of the PBL with inland extent supports the findings of studies like Minder et al. (2015) that describe a transition in the character of the precipitating lake-effect clouds from convective to stratiform. However, an interesting caveat during this event is that the point at which this transition occurs appears to be related to the strength of the PBL flow. Once the heat fluxes are cut off upon landfall, the profile begins stabilizing rapidly, but with the advection of the PBL by the 

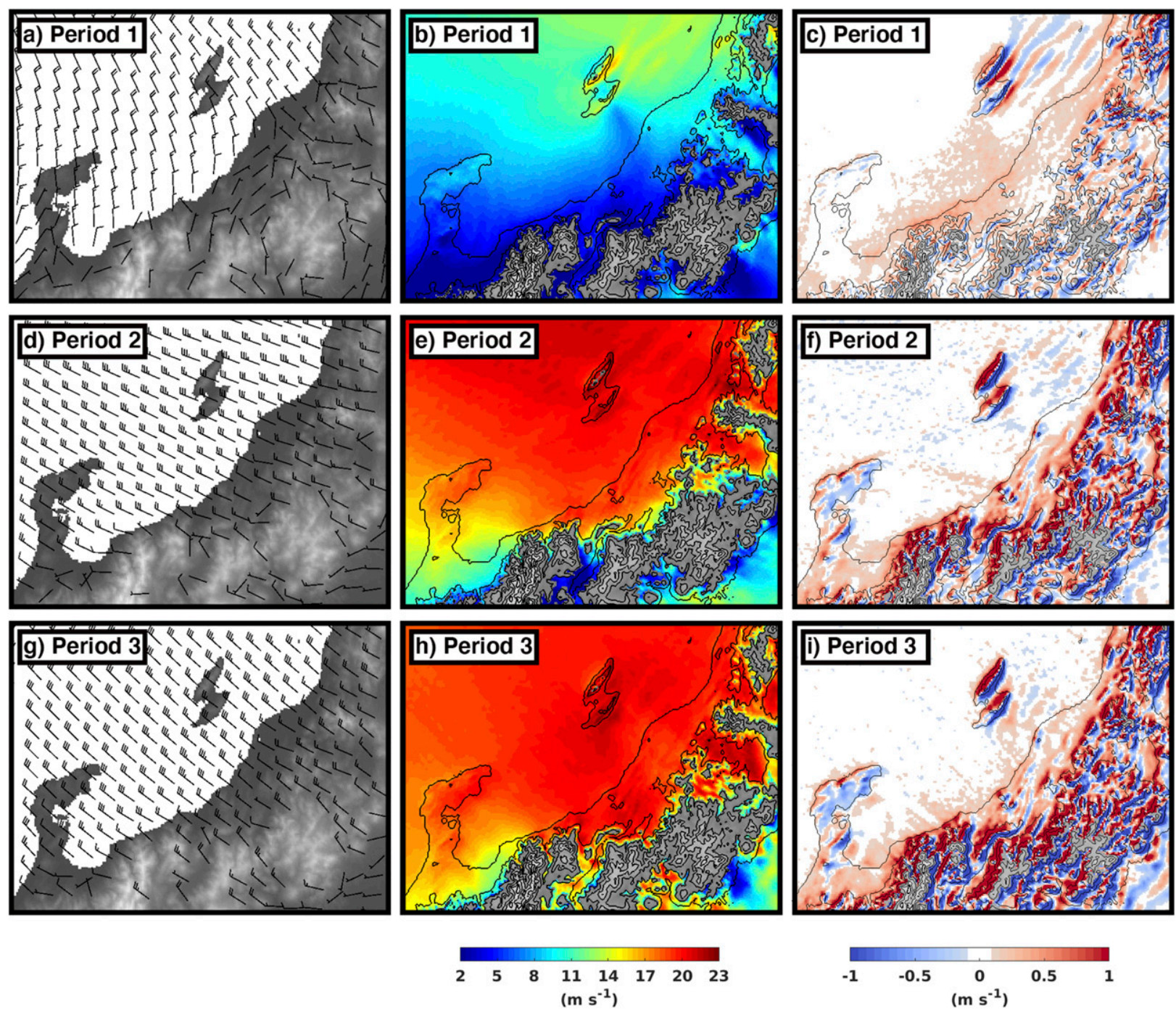

FIG. 8. (a),(d),(g) Mean 10-m wind speed from WRF (full and half barbs denote 5 and $2.5 \mathrm{~m} \mathrm{~s}^{-1}$, respectively), (b),(e),(h) mean $925 \mathrm{hPa}$ wind speed in color fill, and (c),(f),(i) mean $850 \mathrm{hPa}$ vertical velocity for the duration of (a)-(c) period 1, (d)-(f) period 2, and (g)-(i) period 3. The 10-m wind barbs at grid points above $1000 \mathrm{~m}$ MSL are omitted, and the masked regions in the $925 \mathrm{hPa}$ winds and $850 \mathrm{hPa}$ vertical velocity correspond to grid points above those respective levels. Terrain elevation contours every $400 \mathrm{~m}$ MSL.

strong winds in period 3 , the profile does not become stable until it is well over the high terrain.

\section{Dynamical effects}

\section{a. Flow characteristics}

The next step in understanding the LPE distribution during each period is to examine the characteristics of the horizontal and vertical flow fields in WRF. The $10 \mathrm{~m}$ winds during period 1 are fairly uniform in speed and direction in the northwest corner of the domain, but as they approach the coastline a number of changes can be seen (Fig. 8a). Flow moving over the Noto Peninsula slows and appears to be deflected toward the west by the high terrain of the Hida Mountains. Following the $10 \mathrm{~m}$ flow from north to south as it approaches the northern flank of the Hida and Kubiki Mountains, speed decreases right up to the base of the mountains. This rapid deceleration of the flow is also evident in $925 \mathrm{hPa}$ wind speed, occurring in well-defined areas (Fig. 8b). Slowing or blocked flow extends upstream from all of the high barriers in the southern portion of the study region, including the Hida, Kubiki, and SW Echigo Mountains. The $925 \mathrm{hPa}$ flow is blocked over the southern half of the Echigo Plain, but this signature disappears abruptly over the northern Echigo Plain, likely related to the lower 
and/or less continuous barrier of the Central and $\mathrm{N}$ Echigo mountains in this area compared to the SW Echigo Mountains (Fig. 8b). This is also evident in the $10 \mathrm{~m}$ winds, as flow over the SOJ approaching the coastline of Echigo Plain has a generally northwesterly direction, but flow on land over the southern half of the Echigo Plain is northeasterly, directed parallel to the highest terrain and then channeled up the Chikuma Valley (Fig. 8a). The $10 \mathrm{~m}$ flow in the northern half of the Echigo Plain behaves differently, however, with flow making landfall and moving across the mountains, instead of along them. Winds in the $\mathrm{N}$ Echigo Mountains are generally cross barrier and maintain much of their speed (Figs. 8a,b).

The vertical velocity field at $850 \mathrm{hPa}$ shows a broad and continuous area of ascent extending from southern Toyama bay, along the base of the Hida and Kibuki mountains, and northeastward along the shoreline in the southern half of the Echigo Plain (Fig. 8c). There are also positive and negative vertical velocity couplets corresponding, respectively, to the windward and leeward sides of low to moderate elevation terrain in the northern half of the study region where the flow is able to surmount the barrier, in addition to a lee-wave signature from Sado Island. Note that all of these areas of ascent, with the exception of the Sado Island lee waves, correspond well with the regions of moderate to heavy precipitation (both simulated and observed) during period 1 (cf. Figs. 6b and 8c).

The flow changes dramatically in period 2 . The $10 \mathrm{~m}$ and $925 \mathrm{hPa}$ winds are stronger, and though some channeling by the high terrain remains in inland areas, are generally oriented cross barrier in areas where along-barrier flow was present in period 1 (Figs. 8d,e). The only remaining area of deceleration is upwind of the Hida Mountains, which are the highest range in the region. The broad area of ascent at $850 \mathrm{hPa}$ noted in period 1 is no longer present (Fig. 8f). Instead, there are strong vertical velocity couplets over all the major terrain features in the region.

Period 3 features $10 \mathrm{~m}$ wind speeds similar to or slightly stronger $\left(15-17.5 \mathrm{~m} \mathrm{~s}^{-1}\right)$ than those during period 2, generally oriented normal to all of the mountain ranges (Fig. $8 \mathrm{~g}$ ). A change is especially evident in the Chikuma Valley, which is oriented normal to the flow and exhibited some flow channeling in period 2, but switches to cross-valley flow in period 3 . There is almost no deceleration of the flow, though perhaps a small area still remains upwind of the Hida Mountains (Fig. 8h), with vertical velocity couplets over the terrain features of greater magnitude (Fig. 8i).

\section{b. Nondimensional mountain height $(\hat{H})$}

We next examine vertical cross sections of $\hat{H}$ along transects T1 and T2 (Fig. 1b). Following Ohigashi et al. (2014), we define at a given point

$$
\hat{H}=\frac{N\left(h_{m}-Z\right)}{U},
$$

where $N$ is the Brunt-Väisälä frequency at the point (we use the $N_{m}$ where relative humidity exceeds $90 \%$, and $N_{d}$ elsewhere), $h_{m}$ is the height of the barrier along the given transect (2000 and $2600 \mathrm{~m}$ for T1 and T2, respectively), $Z$ is the height MSL of the point, and $U$ is the component of the wind speed normal to the barrier at the point. We also examined $\hat{H}$ using $N_{d}$ everywhere, and as in V19, the behavior of the flow was well represented, with both formulas indicating a similar overall flow regime (blocked versus unblocked) for each period. However, because the formula accounting for moist ascent is technically the most physically sound, we use it for all values of $\hat{H}$ subsequently discussed.

In period 1 , the mean $\hat{H}$ is relatively high along $\mathrm{T} 1$, especially over the coastal lowlands and foothills upwind of the SW Echigo Mountains where values exceed 5 (Fig. 9a). The strongest low-level ascent along T1 appears to be at the upstream edge of this blocked and slightly cooler Echigo Plain air mass, where the impinging flow from the SOJ ascends over it. Along T2, with the much higher barrier of the Hida Mountains, the airmass is blocked farther upstream over the SOJ (Fig. 9b). There is even a return circulation at some points over Toyama Bay, with flow ascending and then moving upwind in the blocked layer. Along both transects, $\hat{H}$ is undefined in the lowest $\sim 0.75 \mathrm{~km}$ due to imaginary values of $N$, but this layer of convective instability does not extend high enough to change the fact that the PBL as a whole is a blocked airmass. It is unclear (and beyond the scope of this study) whether this is an artifact of the WRF PBL, or present over the SOJ in reality, but it warrants further investigation. In period 2 the increased velocity relative to period 1 , and even lower stability, result in little or no flow blocking over T1 and T2 (Figs. 9c,d). Values of $\hat{H}$ are even lower in period 3 , when uninhibited flow occurs over the barriers (Figs. 9e,f).

\section{c. Air parcel trajectories}

To provide a Lagrangian perspective on the airflow, forward air parcel trajectories are computed beginning at 45 points in the study region for each period. 11 trajectories originate at the surface along the shoreline, 11 at the surface $\sim 50 \mathrm{~km}$ upstream, 13 at $500 \mathrm{~m}$ MSL along the shoreline, and 10 at $500 \mathrm{~m} \mathrm{MSL} \sim 50 \mathrm{~km}$ upstream 

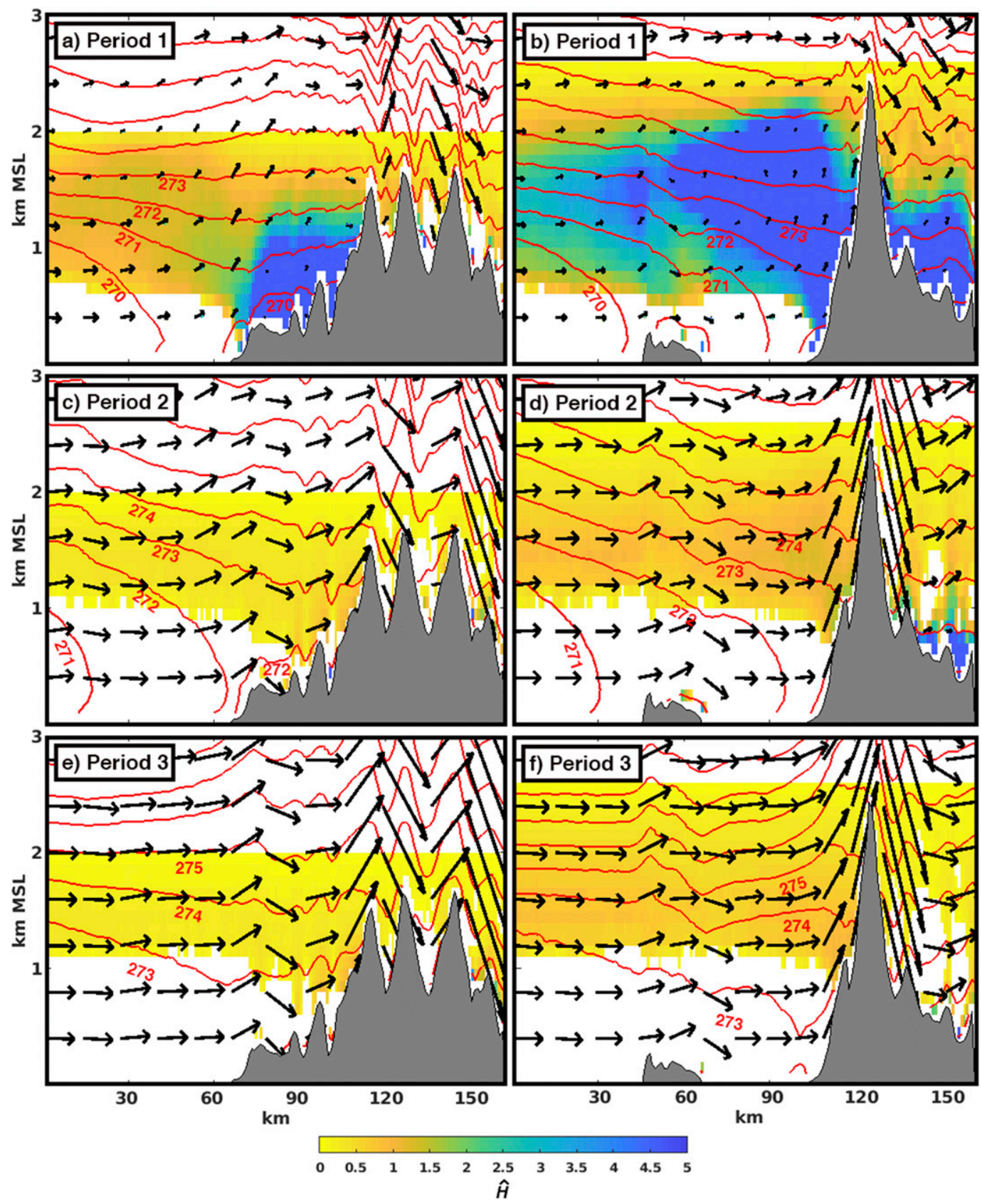

FIG. 9. Cross sections along (a),(c),(e) T1 and (b),(d),(f) T2 with potential temperature contours in red and mean $\hat{H}$ for each period, computed using the moist Brunt-Väisälä frequency at points with relative humidity $>90 \%$ and dry Brunt-Väisälä frequency elsewhere, in color fill. White areas indicate where $\hat{H}$ is undefined due to an imaginary value of the Brunt-Väisälä frequency or an elevation higher than $h_{m}(>2000$ and $>2600 \mathrm{~m}$ for T1 and T2, respectively). Transect-parallel winds are indicated by the vectors.

(Fig. 10). The launch points of the trajectories were selected to provide a quasi-continuous coast-parallel line, while mitigating any excessive overlap that rendered the paths indistinguishable to the reader. We use 2-min model output for the subperiods of trajectory calculation, and determine position in an "offline" method using a second-order semi-implicit discretization method from Miltenberger et al. (2013) using code from Gowan (2019). In period 1 , the surface and $500 \mathrm{~m}$ trajectories launched in the vicinity of Toyama Bay and the Noto Peninsula are deflected toward the SW, generally remaining at low levels (Figs. 10a,b). The exception to this is 

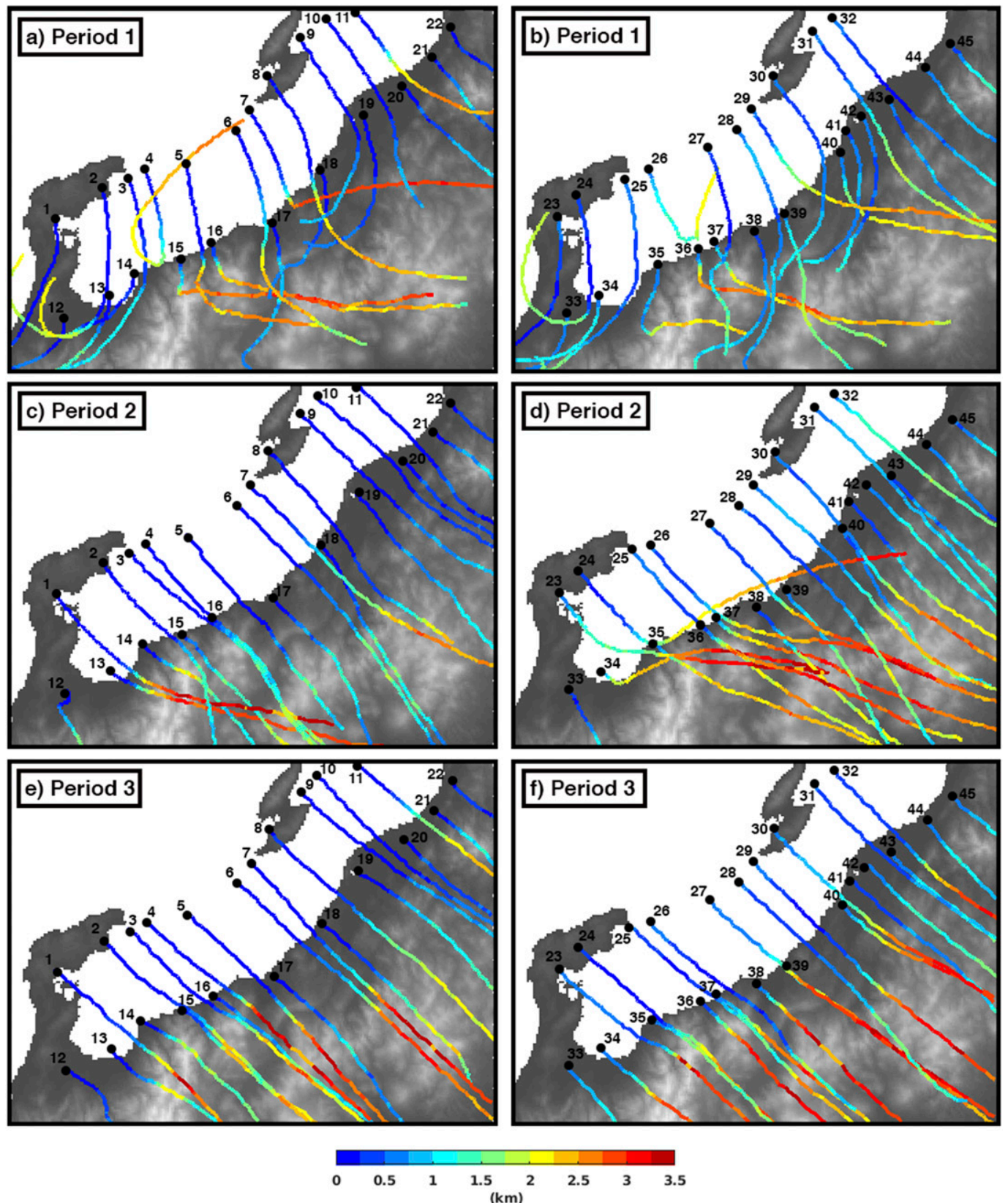

FIG. 10. Air parcel trajectories launched from the black dots, originating at (a),(c),(e) $0 \mathrm{~m} \mathrm{MSL}$ and (b),(d),(f) $500 \mathrm{~m}$ MSL. The height of a parcel ( $\mathrm{km}$ MSL) at each time is indicated by its color, following the scale.

trajectory 4 in Fig. 10a and trajectory 26 in Fig. 10b; they turn against the upper-level flow as they ascend, a likely symptom of the return circulation present up against the Hida Mountains in Fig. 9b. Along the northern Hida and Kubiki Mountains, trajectories 15, 16,36, and 37 ascend over the barrier. Note that this area is part of the broad region of persistent ascent and heavy precipitation during period 1 (see Figs. $8 \mathrm{a}-\mathrm{c}$ and $6 \mathrm{~b}$ ). Over the Echigo Plain, most trajectories launched over its southern half
$(17,18,19,38,41,42)$ generally exhibit characteristics of blocking, while many launched upwind over the SOJ appear to ascend over this blocked air $(6,7,8,29)$. The area where these trajectories ascend over the blocked low-level air is also part of the broad region of persistent ascent and heavy precipitation during period 1 (see Figs. $8 \mathrm{a}-\mathrm{c}$ and $6 \mathrm{~b}$ ). Meanwhile, trajectories over the northern half of the Echigo Plain at all levels ascend the terrain fairly readily. 
Trajectories launched during period 2 readily ascend the terrain, though a few exhibit some deflection upwind of the highest terrain in the study region, the Hida Mountains. (Figs. 10c,d). The addition of eastward motion with height is a result of the wind profile during this period, with a transition to westerly winds above $800 \mathrm{hPa}$ (Fig. 4e). Trajectories in period 3 rise rapidly to high elevation over the terrain, and at all levels move southeastward due to the unidirectional wind profile during this period (Figs. 10e,f). They spend relatively little time over the terrain before rapidly reaching the edge of the domain.

\section{Moist processes}

The final step in understanding the LPE distribution during each period is to examine the characteristics of moist processes. To accomplish this, we examine the relative humidity $(\mathrm{RH})$, Integrated Vapor Transport (IVT), and hydrometeor mixing ratio $\left(Q_{h}\right)$ along each transect. IVT provides a measure of the upslope moisture flux, which can be strongly correlated with orographic precipitation rates (Rutz et al. 2014). Along $\mathrm{T} 1$ and T2, we define IVT as

$$
\mathrm{IVT}=\frac{1}{g} \int_{P_{\mathrm{sfc}}}^{P_{5 \mathrm{~km}}} q \mathbf{V} d p,
$$

where $g$ is the gravitational acceleration, $q$ is the specific humidity, $\mathbf{V}$ is the transect-parallel component of the wind, $P_{\text {sfc }}$ is the surface pressure, and $P_{5 \mathrm{~km}}$ is the pressure at $5 \mathrm{~km}$ above ground. The integration is performed up to $5 \mathrm{~km}$ because the sea-effect PBL and precipitation processes in this case are confined below this level. We define $Q_{h}$ as the sum of the cloud water, cloud ice, graupel, and snow mixing ratios from the Thompson microphysics scheme. The production of hydrometeors (increasing $Q_{h}$ ) acts to decrease IVT, and other important sources of IVT reduction in this case would be increased flow normal to the plane of the cross section and vertical transport across the $5 \mathrm{~km}$ level (likely small).

During period 1 , the moist PBL extends to around $3.8 \mathrm{~km}$ MSL over the SOJ (note the rapid drying above this level), and becomes shallower as it moves over land and the precipitating clouds decay, dramatically so as the flow accelerates over the highest portion of the transect and plunges in the lee (Figs. 11a,b), resembling the sub-to-supercritical flow regime of shallow water depicted in Durran (1986). Despite the deep moisture, the low wind speeds result in a very low IVT $\left(<50 \mathrm{~kg} \mathrm{~m}^{-1} \mathrm{~s}^{-1}\right)$ over the barrier along $\mathrm{T} 1$ and T2. The maximum $Q_{h}$ along $\mathrm{T} 1$ is near the coast where the flow converges with and ascends over the blocked flow in the Echigo Plain (Fig. 12a), as discussed in the previous section. $Q_{h}$ declines quickly with inland extent, approaching zero at the first major peak. Along T2, the maximum is right at the shoreline along the base of the Hida Mountains, with few hydrometeors above about $2 \mathrm{~km}$ (Fig. 12b). For both T1 and T2, the maximum in $Q_{h}$ is approximately collocated with local maxima in vertical velocity (cf. Figs. 8c and 12a,b), and due to the low wind speeds and modest vertical velocities, hydrometeors do not move very far downstream from this maximum.

In period 2 , the PBL extends to $\sim 3 \mathrm{~km}$ MSL over the SOJ, but with the flow now surmounting the barrier, the height of the PBL top increases to $\sim 4 \mathrm{~km}$ MSL over the terrain (Figs. 11c,d). The IVT correspondingly increases, reaching $\sim 100 \mathrm{~kg} \mathrm{~m}^{-1} \mathrm{~s}^{-1}$ at the foot of the barrier along T1 before gradually decreasing. The $Q_{h}$ maximum shifts over the first high peak along T1, and the higher horizontal and vertical velocities allow larger hydrometeor mixing ratios to persist farther downstream (Fig. 12c). Along T2 the $Q_{h}$ maximum is over the crest of the barrier, with a similar increase in the downstream advection and spillover of hydrometeors into the lee (Fig. 12d). There is also an increase in the height of the cloud base compared to period 1 , and beginning near cloud base, a decrease in $Q_{h}$ toward the ground, likely indicating some subcloud sublimation of hydrometeors.

The PBL in period 3 is shallower over the SOJ $(\sim 2 \mathrm{~km}$ MSL) than during previous periods, evident in both $\mathrm{RH}$ (Figs. 11e,f) and cloud tops (Figs. 12e,f), potentially as a result of the large-scale subsidence beginning in the upper levels during this period. Upon ascending the barriers though, it deepens dramatically, with the top extending as high as $4 \mathrm{~km}$ MSL. The further increase in barrier-normal flow velocity into period 3 also appears to correspondingly increase the downstream advection and spillover of hydrometeors into the lee. Cross-barrier IVT values in period $3\left(110 \mathrm{~kg} \mathrm{~m}^{-1} \mathrm{~s}^{-1}\right.$ at the foot of the barrier along T1) are similar to or slightly greater than period 2, which makes them again well-correlated with the LPE rates over the high terrain. However, the LPE over the lowlands and SOJ are a different story, with the lowest values of the study (Fig. 6) despite the high IVT and high wind speeds. Period 3 has the driest low-level $\mathrm{RH}$ and the highest cloud bases of the periods, and in the $Q_{h}$ field very few hydrometeors over the SOJ and lowlands make it to the surface, suggesting substantial subcloud sublimation of hydrometeors (Figs. 12e,f).

Greater subcloud sublimation over lowland areas relative to higher terrain has been suggested to be a mechanism that leads to reduced precipitation over lowland areas during some lake- and sea-effect cases (Murakami et al. 1994; Steenburgh 2003; Minder et al. 2015; Campbell et al. 2016). To examine this process, we 

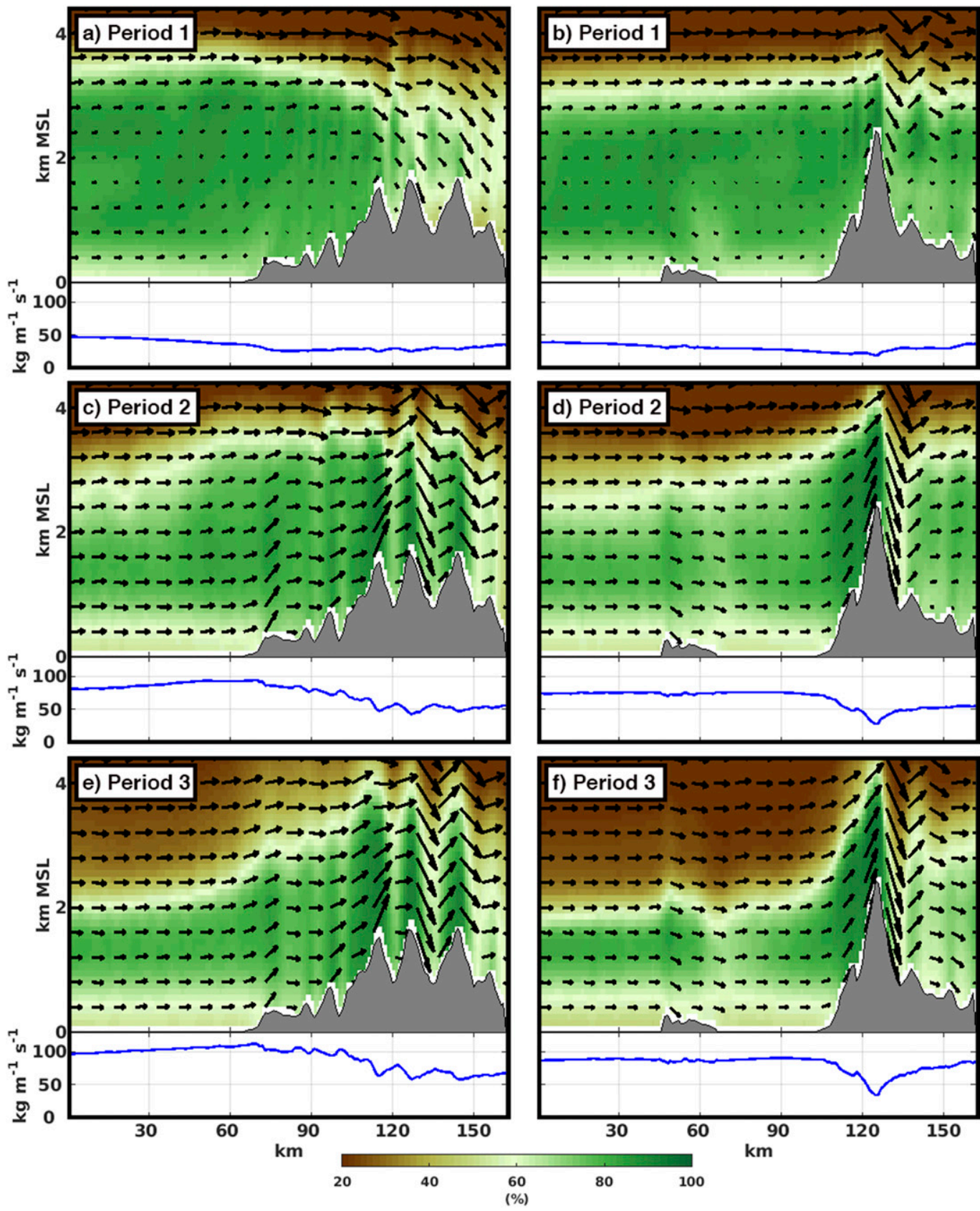

FIG. 11. Cross sections along (a),(c),(e) T1 and (b),(d),(f) T2 with mean relative humidity in color fill according to the scale, with the blue line indicating IVT along the transect. Transect-parallel winds are indicated by the vectors.

focus on the hydrometeor condensation, deposition, evaporation, and sublimation tendency from the microphysics scheme for the first seven model levels (equal to approximately the lowest $1 \mathrm{~km}$ over the lowlands). Plotting the total mass change as a result of this term for each period, divided by the total LPE mass during the period, illustrates the effects of subcloud sublimation well (Fig. 13). Period 1, with the deep moisture throughout the column, sees relatively little loss to sublimation over the lowlands and SOJ, especially in the areas of persistent lift and heavy precipitation (cf. Figs. 6b, 8c, 13a). Sublimation increases for period 2, where low levels are a bit drier (Fig. 13b). The greatest losses occur for period 3, where the low levels are the driest of the study period (Fig. 13c). Therefore, subcloud sublimation appears to play a role in the differing LPE distributions between periods 2 and 3 . 


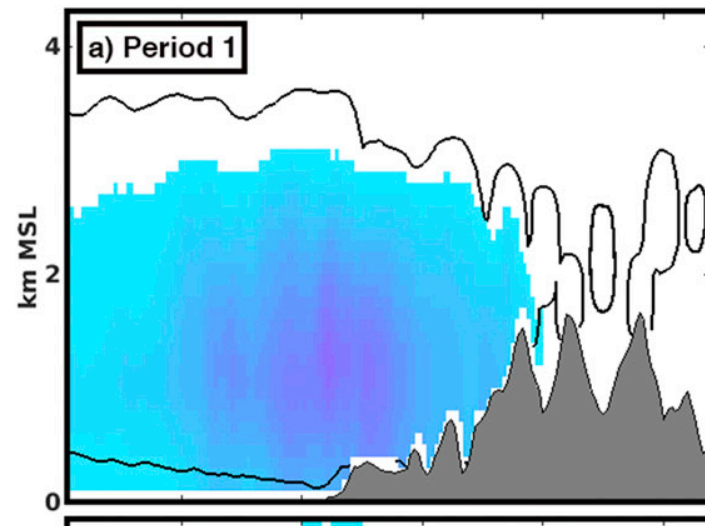

\section{b) Period 1}
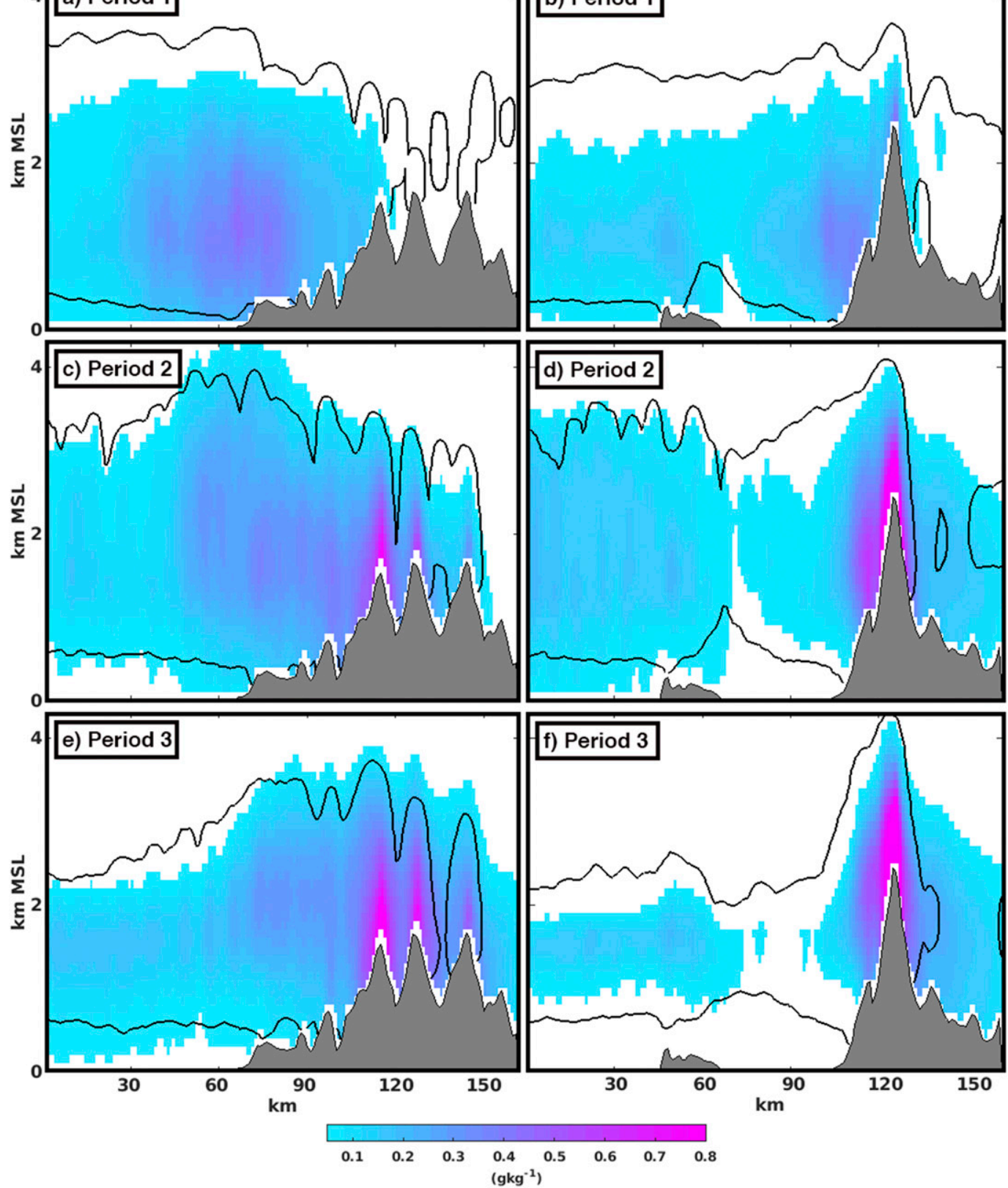

FIG. 12. Mean hydrometeor meteor mixing ratio for each period (color filled following scale) along (a),(c),(e) Transect 1 and (b),(d),(f) Transect 2. Black contour indicates boundary of cloud water mixing ratio $>10^{-3} \mathrm{~g} \mathrm{~kg}^{-1}$.

As discussed in section 3, the WRF PBL is shallower and drier in all periods than observed, with the dry bias strongest in periods 1 and 2. Subcloud sublimation is quite sensitive to these differences, as it is strongly dependent on humidity. If the PBL humidity were closer to observed, the WRF LPE totals in the lowlands would likely increase, especially for periods 1 and 2, which would bring them closer to the gauge and radar-estimated values in most lowland areas, further increasing the effect of subcloud sublimation on the differing LPE distributions between periods 2 and 3 .

\section{Summary and conclusions}

This study has examined the variability in the distribution and enhancement of LPE during a heavy seaeffect snowstorm from 2 to 7 February 2010 in the Hokuriku region. Period 1 featured heavy snowfall in 

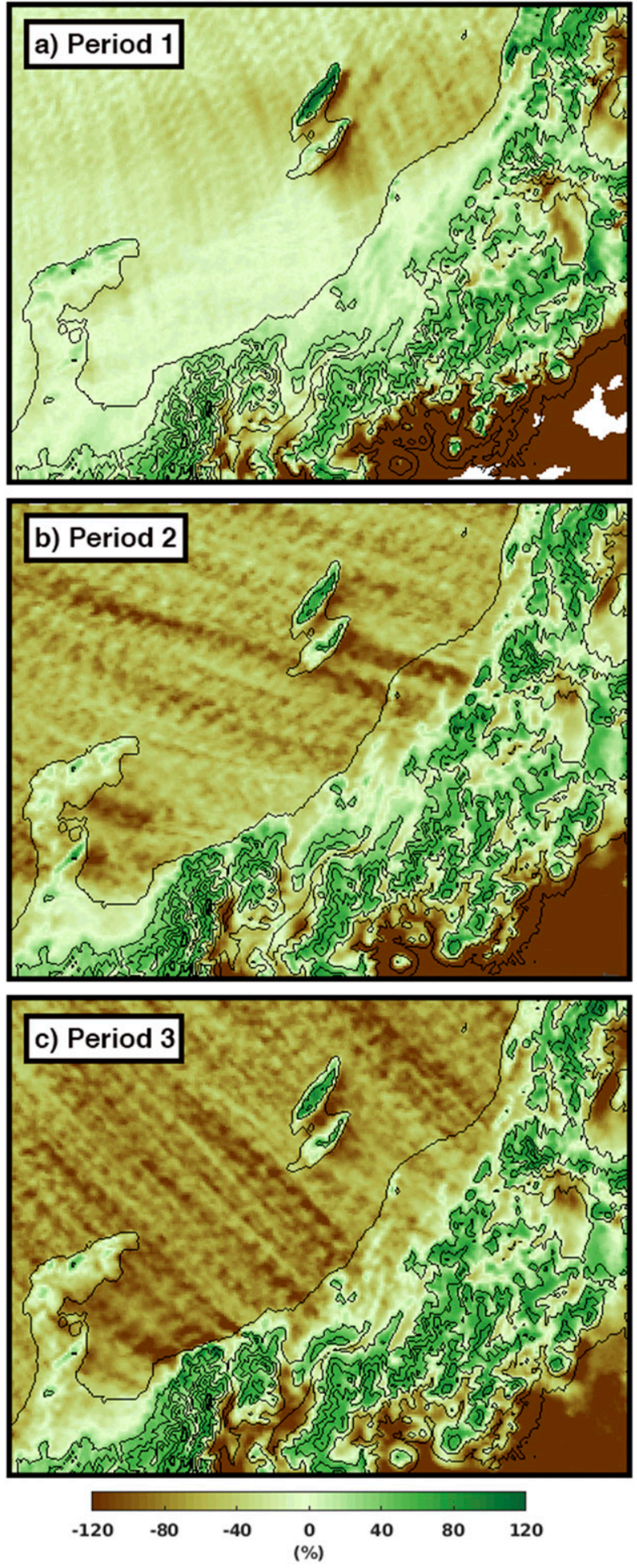

FIG. 13. Ratio of the total amount, color-filled according to the scale, of condensation and deposition (positive values), or evaporation and sublimation (negative values) from the Thompson microphysics scheme in the lowest 7 model levels to the total accumulated precipitation for (a) period 1, (b) period 2, and (c) period 3 lowland areas and little or no snowfall over the higher elevations. In period 2 the LPE maximum shifted downstream and higher in elevation, with the higher elevations receiving heavy snowfall and only light or moderate amounts in the lowlands. In period 3 the LPE maximum shifted even farther downstream and higher into the mountains, with heavy snowfall at high elevations and into the lee, and little or no snowfall in the lowlands.

The strength of the cross-barrier component of the flow primarily determined the evolution and distribution of precipitation during the event. Period 1 featured the weakest flow of the event, with blocking of the flow at low levels and weak vertical velocities over the high terrain. Maxima in ascent and LPE during the period were located where the flow ascended 1) over terrainblocked air, 2) at the foot of a high flow-normal barrier, or 3) relatively unimpeded over the lower mountain ranges in the northern portion of the region.

Stronger flow in period 2 surmounted the terrain, producing strong vertical velocity couplets over all major terrain features. There was also stronger cross-barrier moisture transport, and convective instability over the SOJ was the strongest of all three periods. The greatest hydrometeor mixing ratios and LPE totals occurred over the first major peaks, and then LPE totals decreased rapidly with inland extent over the high terrain.

Period 3 had cross-barrier flow velocities slightly stronger than period 2, with LPE and hydrometeor maxima occurring over each high peak, including those downstream of the crest, with spillover of these hydrometeors into the lee of the higher peaks. Moisture transport was slightly greater than period 2, and indeed LPE rates over the high peaks were similar. However, despite the strong moisture transport, period 3 saw almost no precipitation in lowland areas. The difference in lowland LPE between periods 2 and 3 is likely due in part to the slightly drier PBL in period 3 , which resulted in substantial sublimation of hydrometeors. The convective instability over the SOJ also likely played a role. MUCAPE was greater in period 2 than period 3, and as V19 showed, greater CAPE promotes the greater lowland LPE rates that were observed in period 2.

As was found in Minder et al. (2015), convection decayed quickly upon landfall, but the point at which this transition occurred appears to be related to the strength of the flow in the PBL. In the light flow of period 1, the profile stabilizes almost immediately upon landfall. With the rapid advection of the PBL by the strong winds in period 3, the profile does not become stable until it is well inland over the high terrain.

These findings add to our knowledge of lake- and seaeffect systems and of orographic precipitation in general. The enhancement over downstream terrain can be remarkably similar to other orographic precipitation 
regimes, with the control of precipitation distribution and intensity by wind speed also observed in atmospheric river events in California (Neiman et al. 2002; Hughes et al. 2009) and storms in the European Alps (Panziera and Germann 2010). The flow blocking observed during period 1 , and the subsequent ascent maxima upwind of the terrain, are also quite similar to cases in other mountain ranges around the world (e.g., Houze et al. 2001; Neiman et al. 2002; Falvey and Gerreaud 2007; Houze 2012). On the other hand, phenomena such as the effect of sea-induced CAPE on lowland LPE and the stabilization of the PBL with inland extent are unique to the sea-effect regime.

This study did not examine the effects of the transition from $\mathrm{T}$-mode convection in periods 1 and 2 to L-mode in period 3, but some influence on the LPE distribution by mode is likely (e.g., Campbell et al. 2016; Veals et al. 2018). It is also possible that the depth of the precipitating clouds, through effects on precipitation efficiency and intensity (e.g., Kostinski 2008), influences the distribution and intensity of LPE. Therefore, future work should investigate these effects in the Hokuriku and other lake- and sea-effect prone regions.

Acknowledgments. This research was supported by National Science Foundation Grant AGS-1635654 and NASA Grant NNX16AD76G. Any opinions, findings, and conclusions or recommendations expressed in this paper are those of the authors and do not necessarily reflect the views of the funding agencies. Comments and input from Justin Minder, John Horel, Steve Krueger, Tom Gowan, and three anonymous reviewers were extremely beneficial to this work. We thank ECMWF, SIRC, JMA, NCAR, MathWorks, Unidata, and the University of Utah Center for High Performance Computing for the provision of datasets and/or software.

\section{REFERENCES}

Alcott, T. I., and W. J. Steenburgh, 2013: Orographic influences on a Great Salt Lake-effect snowstorm. Mon. Wea. Rev., 141, 2432-2450, https://doi.org/10.1175/MWR-D-12-00328.1.

Asai, T., 1972: Thermal instability of a shear flow turning the direction with height. J. Meteor. Soc. Japan, 50, 525-532, https:// doi.org/10.2151/jmsj1965.50.6_525.

Baines, P. G., 1987: Upstream blocking and airflow over mountains. Annu. Rev. Fluid. Mech., 19, 75-97.

Barcilon, A., J. C. Jusem, and P. G. Drazin, 1979: On the twodimensional, hydrostatic flow of a stream of moist air over a mountain ridge. Geophys. Astrophys. Fluid Dyn., 13, 125-140, https://doi.org/10.1080/03091927908243765.

Byrd, G. P., R. A. Anstett, J. E. Heim, and D. M. Usinski, 1991: Mobile sounding observations of lake-effect snowbands in western and central New York. Mon. Wea. Rev., 119, 23232332, https://doi.org/10.1175/1520-0493(1991)119<2323: MSOOLE $>2.0 . \mathrm{CO} ; 2$.
Campbell, L. S., and W. J. Steenburgh, 2014: Finescale orographic precipitation variability and gap-filling radar potential in Little Cottonwood Canyon, Utah. Wea. Forecasting, 29, 912935, https://doi.org/10.1175/WAF-D-13-00129.1.

— , and - 2017: The OWLeS IOP2b lake-effect snowstorm: Mechanisms contributing to the Tug Hill precipitation maximum. Mon. Wea. Rev., 145, 2461-2478, https://doi.org/10.1175/ MWR-D-16-0461.1.

— — — P. P. Veals, T. W. Letcher, and J. R. Minder, 2016: Lake-effect mode and precipitation enhancement over the Tug Hill Plateau during OWLeS IOP2b. Mon. Wea. Rev., 144, 1729-1748, https://doi.org/10.1175/MWR-D-15-0412.1.

,$- \ldots$, Y. Yamada, M. Kawashima, and Y. Fujiyoshi, 2018: Influences of orography and coastal geometry on a transversemode sea-effect snowstorm over Hokkaido Island, Japan. Mon. Wea. Rev., 146, 2201-2220, https://doi.org/10.1175/MWR-D-170286.1.

Chater, A. M., and A. P. Sturman, 1998: Atmospheric conditions influencing spillover of rainfall to the lee of the Southern Alps, New Zealand. Int. J. Climatol., 18, 77-92, https://doi.org/10.1002/ (SICI)1097-0088(199801)18:1<77::AID-JOC218>3.0.CO;2-M.

Chen, F., and J. Dudhia, 2001: Coupling an advanced land surface-hydrology model with the Penn State-NCAR MM5 modeling system. Part II: Preliminary model validation. Mon. Wea. Rev., 129, 587-604, https://doi.org/10.1175/15200493(2001)129<0587:CAALSH>2.0.CO;2.

Ching, J., R. Rotunno, M. LeMone, A. Martilli, B. Kosovic, P. A. Jimenez, and J. Dudhia, 2014: Convectively induced secondary circulations in fine-grid mesoscale numerical weather prediction models. Mon. Wea. Rev., 142, 3284-3302, https:// doi.org/10.1175/MWR-D-13-00318.1.

Colle, B. A., 2004: Sensitivity of orographic precipitation to changing ambient conditions and terrain geometries: An idealized modeling perspective. J. Atmos. Sci., 61, 588-606, https://doi.org/ 10.1175/1520-0469(2004)061<0588:SOOPTC >2.0.CO;2.

Conrick, R., H. D. Reeves, and S. Zhong, 2015: The dependence of QPF on the choice of boundary- and surface-layer parameterization for a lake-effect snowstorm. J. Appl. Meteor. Climatol., 54, 1177-1190, https://doi.org/10.1175/JAMC-D-140291.1.

Dorman, C. E., R. C. Beardsley, N. A. Dashko, C. A. Friehe, D. Kheilf, K. Cho, R. Limeburner, and S. M. Varlamov, 2004: Winter marine atmospheric conditions over the Japan Sea. J. Geophys. Res., 109, C12011, https://doi.org/10.1029/ 2001JC001197.

C3S, 2017: ERA5: Fifth generation of ECMWF atmospheric re-analyses of the global climate. Copernicus Climate Change Service Climate Data Store, accessed 10 August 2019, https:// cds.climate.copernicus.eu/cdsapp\#!/home.

Dudhia, J., 1989: Numerical study of convection observed during the Winter Monsoon Experiment using a mesoscale two-dimensional model. J. Atmos. Sci., 46, 3077-3107, https://doi.org/10.1175/15200469(1989)046<3077:NSOCOD>2.0.CO;2.

Durran, D. R., 1986: Another look at downslope windstorms. Part I: The development of analogs to supercritical flow in an infinitely deep, continuously stratified fluid. J. Atmos. Sci., $\mathbf{4 3}$, 2527-2543, https://doi.org/10.1175/1520-0469(1986)043<2527: ALADWP $>2.0 . \mathrm{CO} ; 2$.

— , and J. B. Klemp, 1982: On the effects of moisture on the BruntVäisälä frequency. J. Atmos. Sci., 39, 2152-2158, https://doi.org/ 10.1175/1520-0469(1982)039<2152:OTEOMO>2.0.CO;2.

Eito, H., T. Kato, M. Yoshizaki, and A. Adachi, 2005: Numerical simulation of the quasistaitonary snowband observed over the 
southern coastal area of the Sea of Japan on 16 January 2001. J. Meteor. Soc. Japan, 83, 551-576, https://doi.org/10.2151/ jmsj.83.551.

— M. Murakami, C. Muroi, T. Kato, S. Hayashi, H. Kuroiwa, and M. Yoshizaki, 2010: The structure and formation mechanism of transversal cloud bands associated with the Japan-Sea Polar-Airmass Convergence Zone. J. Meteor. Soc. Japan, 88, 625-648, https://doi.org/10.2151/jmsj.2010-402.

Falvey, M., and R. Garreaud, 2007: Wintertime precipitation episodes in central Chile: Associated meteorological conditions and orographic influences. J. Hydrometeor., 8, 171-193, https:// doi.org/10.1175/JHM562.1.

Fraser, A. B., R. C. Easter, and P. V. Hobbs, 1973: A theoretical study of the flow of air and fallout of solid precipitation over mountainous terrain. Part I: Airflow model. J. Atmos. Sci., 30, 801-812, https://doi.org/10.1175/1520-0469(1973)030<0801: ATSOTF $>2.0 . \mathrm{CO} ; 2$.

Galewsky, J., 2008: Orographic clouds in terrain-blocked flows: An idealized modeling study. J. Atmos. Sci., 65, 3460-3478, https:// doi.org/10.1175/2008JAS2435.1.

Garvert, M. F., B. Smull, and C. Mass, 2007: Multiscale mountain waves influencing a major orographic precipitation event. J. Atmos. Sci., 64, 711-737, https://doi.org/10.1175/JAS3876.1.

Geerts, B., Y. Yang, R. Rasmussen, S. Haimov, and B. Pokharel, 2015: Snow growth and transport patterns in orographic storms as estimated from airborne vertical-plane dual-Doppler radar data. Mon. Wea. Rev., 143, 644-665, https://doi.org/ 10.1175/MWR-D-14-00199.1.

Gowan, T. M., 2019: Trajectories. Personal GitHub page, accessed 20 August 2019, https://github.com/tomgowan/trajectories.

Harimaya, T., and M. Sato, 1992: The riming proportion in snow particles falling on coastal areas. J. Meteor. Soc. Japan, 70, 57-65, https://doi.org/10.2151/jmsj1965.70.1_57.

_ , and N. Kanemura, 1995: Comparison of the riming growth of snow particles between coastal and inland areas. J. Meteor. Soc. Japan, 73, 25-36, https://doi.org/10.2151/jmsj1965.73.1_25.

Hong, S.-Y., Y. Noh, and J. Dudhia, 2006: A new vertical diffusion package with an explicit treatment of entrainment processes. Mon. Wea. Rev., 134, 2318-2341, https://doi.org/ 10.1175/MWR3199.1.

Houze, R. A., 2012: Orographic effects on precipitating clouds. Rev. Geophys., 50, RG1001, https://doi.org/10.1029/2011RG000365.

— C. N. James, and S. Medina, 2001: Radar observations of precipitation and airflow on the Mediterranean side of the Alps: Autumn 1998 and 1999. Quart. J. Roy. Meteor. Soc., 127, 2537-2558, https://doi.org/10.1002/qj.49712757804.

Hughes, M., A. Hall, and R. G. Fovell, 2009: Blocking in areas of complex topography, and its influence on rainfall distribution. J. Atmos. Sci., 66, 508-518, https://doi.org/10.1175/2008JAS2689.1.

Iacono, M. J., J. S. Delamere, E. J. Mlawer, M. W. Shephard, S. A. Clough, and W. D. Collins, 2008: Radiative forcing by longlived greenhouse gases: Calculations with the AER radiative transfer models. J. Geophys. Res., 113, D13103, https://doi.org/ 10.1029/2008JD009944.

Ishihara, M., H. Sakakibara, and Z. Yanagisawa, 1989: Doppler radar analysis of the structure of mesoscale snow bands developed between the winter monsoon and the land breeze. J. Meteor. Soc. Japan, 67, 503-520, https://doi.org/10.2151/ jmsj1965.67.4_503.

Jiang, Q., 2003: Moist dynamics and orographic precipitation. Tellus, 55A, 301-316, https://doi.org/10.1034/j.1600-0870.2003.00025.x.

Jiménez, P. A., J. Dudhia, J. F. González-Rouco, J. Navarro, J. P. Montávez, and E. García-Bustamante, 2012: A revised scheme for the WRF surface layer formulation. Mon. Wea. Rev., 140, 898-918, https://doi.org/10.1175/MWR-D-11-00056.1.

Kain, J. S., 2004: The Kain-Fritsch convective parameterization: An update. J. Appl. Meteor., 43, 170-181, https://doi.org/ 10.1175/1520-0450(2004)043<0170:TKCPAU > 2.0.CO;2.

Kostinski, A. B., 2008: Drizzle rates versus cloud depths for marine stratocumuli. Environ. Res. Lett., 3, 045019, https://doi.org/ 10.1088/1748-9326/3/4/045019.

Kusunoki, K., and Coauthors, 2003: Ka-band radar observations of orographic snow clouds and flows across a steep mountain ridge. 31st Conf. on Radar Meteorology, Seattle, WA, P1B.10, https://ams.confex.com/ams/32BC31R5C/webprogram/ 31RADAR.html.

_, M. Murakami, M. Hoshimoto, N. Orikasa, Y. Yamada, H. Mizuno, K. Hamazu, and H. Watanabe, 2004: The characteristics and evolution of orographic snow clouds under weak cold advection. Mon. Wea. Rev., 132, 174-191, https://doi.org/ 10.1175/1520-0493(2004)132<0174:TCAEOO >2.0.CO;2.

— , and Coauthors, 2005: Observations of quasi-stationary and shallow orographic clouds: Spatial distributions of supercooled liquid water and snow particles. Mon. Wea. Rev., 133, 743-751, https://doi.org/10.1175/MWR2874.1.

Magono, C., K. Kikuchi, T. Kimura, S. Tazawa, and T. Kasai, 1966: A study on the snowfall in the winter monsoon season in Hokkaido with special reference to low land snowfall. J. Fac. Sci. Hokkaido Univ. Ser. 7, 11, 287-308.

Manabe, S., 1957: On the modification of air-mass over the Japan Sea when the outburst of cold air predominates. J. Meteor. Soc. Japan, 35, 311-326, https://doi.org/10.2151/jmsj1923.35.6_311.

McMillen, J. D., and W. J. Steenburgh, 2015: Impact of microphysics parameterizations on simulations of the 27 October 2010 Great Salt Lake-effect snowstorm. Wea. Forecasting, 30, 136-152, https://doi.org/10.1175/WAF-D-14-00060.1.

Miltenberger, A. K., S. Pfahl, and H. Wernli, 2013: An online trajectory module (version 1.0) for the nonhydrostatic numerical weather prediction model COSMO. Geosci. Model Dev., 6, 1989-2004, https://doi.org/10.5194/gmd-6-1989-2013.

Minder, J. R., D. R. Durran, G. H. Roe, and A. M. Anders, 2008: The climatology of small-scale orographic precipitation over the olympic mountains: Patterns and processes. Quart. J. Roy. Meteor. Soc., 134, 817-839, https://doi.org/10.1002/qj.258.

, T. W. Letcher, L. S. Campbell, P. G. Veals, and W. J. Steenburgh, 2015: The evolution of lake-effect convection during landfall and orographic uplift as observed by profiling radars. Mon. Wea. Rev., 143, 4422-4442, https://doi.org/10.1175/ MWR-D-15-0117.1.

Miura, Y., 1986: Aspect ratios of longitudinal rolls and convection cells observed during cold air outbreaks. J. Atmos. Sci., 43, 26-39, https://doi.org/10.1175/1520-0469(1986) $043<0026$ :AROLRA $>2.0 . \mathrm{CO} ; 2$.

Miyazawa, S., 1968: A mesoclimatological study on heavy snowfall-A synoptic study on the mesoscale disturbances. Pap. Meteor. Geophys., 19, 487-550, https://doi.org/10.2467/ mripapers1950.19.4_487.

Murakami, M., T. L. Clark, and W. D. Hall, 1994: Numerical simulations of convective snow clouds over the seas of Japan; two-dimensional simulations of mixed layer development and convective snow cloud formation. J. Meteor. Soc. Japan, 72, 43-62, https://doi.org/10.2151/jmsj1965.72.1_43.

Nakai, S., K. Iwanami, R. Misumi, S.-G. Park, and T. Kobayashi, 2005: A classification of snow clouds by Doppler radar observations at Nagaoka, Japan. SOLA, 1, 161-164, https:// doi.org/10.2151/SOLA.2005-042. 
— precipitation intensity from radar with model results around coastal topography during cold-air outbreak periods. 13th Conf. on Mountain Meteorology, Whistler, BC, Canada, Amer. Meteor. Soc., P1.20, https://ams.confex.com/ams/ 13MontMet17AP/webprogram/Paper141037.html.

Neiman, P. J., F. M. Ralph, A. B. White, D. E. Kingsmill, and P. O. G. Persson, 2002: The statistical relationship between upslope flow and rainfall in California's coastal mountains: Observations during CALJET. Mon. Wea. Rev., 130, 1468-1492, https://doi.org/ 10.1175/1520-0493(2002)130<1468:TSRBUF>2.0.CO;2.

Niziol, T. A., W. R. Snyder, and J. S. Waldstreicher, 1995: Winter weather forecasting throughout the eastern United States. Part IV: Lake effect snow. Wea. Forecasting, 10, 61-77, https://doi.org/10.1175/1520-0434(1995)010<0061:WWFTTE> 2.0.CO;2.

Ohigashi, T., and K. Tsuboki, 2005: Structure and maintenance process of stationary double snowbands along the coastal region. J. Meteor. Soc. Japan, 83, 331-349, https://doi.org/ 10.2151/jmsj.83.331.

— Japan-Sea Polar-Airmass Convergence Zone associated with the passage of a mid-tropospheric cold core. J. Meteor. Soc. Japan, 85, 633-662, https://doi.org/10.2151/jmsj.85.633.

,,-- Y. Schusse, and H. Uyeda, 2014: An intensification process of a winter broad cloud band on a flank of the mountain region along the Japan-Sea coast. J. Meteor. Soc. Japan, 92, 71-93, https://doi.org/10.2151/jmsj.2014-105.

Panziera, L., and U. Germann, 2010: The relation between airflow and orographic precipitation on the southern side of the Alps as revealed by weather radar. Quart. J. Roy. Meteor. Soc., 136, 222-238, https://doi.org/10.1002/qj.544.

Pierrehumbert, R. T., and B. Wyman, 1985: Upstream effects of mesoscale mountains. J. Atmos. Sci., 42, 977-1003, https:// doi.org/10.1175/1520-0469(1985)042<0977:UEOMM >2.0.CO;2

Reeves, H. D., and D. T. Dawson, 2013: The dependence of QPF on the choice of microphysical parameterization for lakeeffect snowstorms. J. Appl. Meteor. Climatol., 52, 363-377, https://doi.org/10.1175/JAMC-D-12-019.1.

Rutz, J. J., W. J. Steenburgh, and F. M. Ralph, 2014: Climatological characteristics of atmospheric rivers and their inland penetration over the western United States. Mon. Wea. Rev., 142, 905-921, https://doi.org/10.1175/MWR-D-13-00168.1.

Sinclair, M. R., D. S. Wratt, R. D. Henderson, and W. R. Gray, 1997: Factors affecting the distribution and spillover of precipitation in the Southern Alps of New Zealand-A case study. J. Appl. Meteor., 36, 428-442, https://doi.org/ 10.1175/1520-0450(1997)036<0428:FATDAS > 2.0.CO;2.

Skamarock, W. C., and Coauthors, 2008: A description of the Advanced Research WRF version 3. NCAR Tech. Note NCAR/ TN-475+STR, 113 pp., https://doi.org/10.5065/D68S4MVH.

Smith, R. B., 1989: Mountain-induced stagnation points in hydrostatic flow. Tellus, 41A, 270-274, https://doi.org/10.1111/ j.1600-0870.1989.tb00381.x.

— tation. J. Atmos. Sci., 61, 1377-1391, https://doi.org/10.1175/ 1520-0469(2004)061<1377:ALTOOP >2.0.CO;2.

Smolarkiewicz, P. K., and R. Rotunno, 1989: Low Froude number flow past three-dimensional obstacles. Part I: Baroclinically generated lee vortices. J. Atmos. Sci., 46, 1154-1164, https:// doi.org/10.1175/1520-0469(1989)046<1154:LFNFPT>2.0.CO;2.

Steenburgh, W. J., 2003: One hundred inches in one hundred hours: Evolution of a Wasatch Mountain winter storm cycle.
Wea. Forecasting, 18, 1018-1036, https://doi.org/10.1175/ 1520-0434(2003)018<1018:OHIIOH > 2.0.CO;2.

—, and L. S. Campbell, 2017: The OWLeS IOP2b lake-effect snowstorm: Shoreline geometry and the mesoscale forcing of precipitation. Mon. Wea. Rev., 145, 2421-2436, https://doi.org/ 10.1175/MWR-D-16-0460.1.

Tachibana, Y., 1995: A statistical study of the snowfall distribution on the Japan Sea side of Hokkaido and its relation to synopticscale and meso-scale environments. J. Meteor. Soc. Japan, 73, 697-715, https://doi.org/10.2151/jmsj1965.73.3_697.

Thompson, G., P. R. Field, R. M. Rasmussen, and W. D. Hall, 2008: Explicit forecasts of winter precipitation using an improved bulk microphysics scheme. Part II: Implementation of a new snow parameterization. Mon. Wea. Rev., 136, 5095-5115, https://doi.org/10.1175/2008MWR2387.1.

Vasiloff, S., 2001: WSR-88D performance in northern Utah during the winter of 1998-1999. Part I: Adjustments to precipitation estimates. NOAA/Western Regional Tech. Attachment 01-02, 8 pp., https://www.weather.gov/media/ wrh/online_publications/TAs/ta0102.pdf.

Veals, P. G., W. J. Steenburgh, and L. Campbell, 2018: Factors affecting the inland and orographic enhancement of lakeeffect precipitation over the Tug Hill Plateau. Mon. Wea. Rev., 146, 1745-1762, https://doi.org/10.1175/MWR-D-17-0385.1.

, — S. Nakai, and S. Yamaguchi, 2019: Factors affecting the inland and orographic enhancement of sea-effect precipitation in the Hokuriku Region of Japan. Mon. Wea. Rev., 147, 31213143, https://doi.org/10.1175/MWR-D-19-0007.1.

Watson, C. D., and T. P. Lane, 2012: Sensitivities of orographic precipitation to terrain geometry and upstream conditions in idealized simulations. J. Atmos. Sci., 69, 1208-1231, https:// doi.org/10.1175/JAS-D-11-0198.1.

— tation to terrain geometry in idealized simulations. J. Atmos. Sci., 71, 3068-3089, https://doi.org/10.1175/JAS-D-13-0318.1.

West, T. K., W. J. Steenburgh, and G. G. Mace, 2019: Characteristics of sea-effect clouds and precipitation over the Sea of Japan region as observed by A-Train satellites. J. Geophys. Res. Atmos., 124, 1322-1335, https://doi.org/ 10.1029/2018JD029586.

Yamada, Y., M. Murakami, H. Mizuno, M. Maki, S. Nakai, and K. Iwanami, 2010: Kinematic and thermodynamical structures of longitudinal-mode snow bands over the Sea of Japan during cold-air outbreaks. Part I: Snow bands in large vertical shear environment in the band-transverse direction. J. Meteor. Soc. Japan, 88, 673-718, https://doi.org/10.2151/jmsj.2010-404.

Yoshihara, H., M. Kawashima, K. I. Arai, J. Inoue, and Y. Fujiyoshi, 2004: Doppler radar study on the successive development of snowbands at a convergence line near the coastal region of Hokuriku District. J. Meteor. Soc. Japan, 82, 1057-1079, https:// doi.org/10.2151/jmsj.2004.1057.

Yoshizaki, M., T. Kato, H. Eito, S. Hayashi, and W.-K. Tao, 2004: An overview of the field experiment "winter Mesoscale Convective Systems (MCSs) over the Japan Sea in 2001", and comparisons of the cold-air outbreak case (14 January) between analysis and a non-hydrostatic cloud-resolving model. J. Meteor. Soc. Japan, 82, 1365-1387, https://doi.org/10.2151/jmsj.2004.1365.

Yuter, S. E., D. A. Stark, J. A. Crouch, M. J. Payne, and B. A. Colle, 2011: The impact of varying environmental conditions on the spatial and temporal patterns of orographic precipitation over the Pacific Northwest near Portland, Oregon. J. Hydrometeor., 12, 329-351, https://doi.org/10.1175/2010JHM1239.1. 